\title{
Multilayer observation and estimation of the snowpack cold content in a humid boreal coniferous forest in eastern Canada
}

\author{
Achut Parajuli ${ }^{1,2}$, Daniel F. Nadeau ${ }^{1,2}$, François Anctil ${ }^{1,2}$, Marco Alves ${ }^{1,2}$ \\ ${ }^{1}$ Department of Civil and Water Engineering, Université Laval, Québec, Canada \\ $5{ }^{3}$ CentrEau, Quebec Water Research Centre, Université Laval, Québec, Canada
}

Correspondence to: Achut Parajuli (achut.parajuli.1@ulaval.ca)

\begin{abstract}
Cold content $(C C)$ is an internal energy state within a snowpack and is defined by the energy deficit required to attain isothermal snowmelt temperature $\left(0^{\circ} \mathrm{C}\right)$. For any snowpack, fulfilling the cold content deficit is a pre-requisite before the onset of the snowmelt. Cold content for a given snowpack thus plays a critical role because it affects both the timing and

10 the rate of snowmelt. Estimating the cold content is a labour-intensive task as it requires extracting in-situ snow temperature and density. Hence, few studies have focused on characterizing this snowpack variable. This study describes the multilayer cold content of a snowpack and its variability across four sites with contrasting canopy structures within a coniferous boreal forest in southern Québec, Canada, throughout winter 2017-18. The analysis was divided into two steps. In the first step, the observed $C C$ data from weekly snowpits for $60 \%$ of the snow cover period were examined. During the second step, a

15 reconstructed time series of $C C$ was produced and analyzed to highlight the high-resolution temporal variability of $C C$ for the full snow cover period. To accomplish this, the Canadian Land Surface Scheme (CLASS; featuring a single-layer snow model) was first implemented to obtain simulations of the average snow density at each of the four sites. Next, an empirical procedure was used to produce realistic density profiles, which, when combined with in situ continuous snow temperature measurements from an automatic profiling station, provides a time series of $C C$ estimates at half-hour intervals for the entire winter. At the

20 four sites, snow persisted on the ground for 218 days, with melt events occurring on 42 of those days. Based on snowpit observations, the largest mean $C C\left(-2.62 \mathrm{MJ} \mathrm{m}^{-2}\right)$ was observed at the site with the thickest snow cover. The maximum difference in mean $C C$ between the four study sites was $-0.47 \mathrm{MJ} \mathrm{m}^{-2}$, representing a site-to-site variability of $20 \%$. Before analyzing the reconstructed $C C$ time series, a comparison with snowpit data confirmed that CLASS yielded reasonable estimates of the snow water equivalent $(S W E)\left(\mathrm{R}^{2}=0.64\right.$ and percent bias $\left.(\mathrm{Pbias})=-17.1 \%\right)$, bulk snow density $\left(\mathrm{R}^{2}=0.71\right.$

25 and Pbias $=1.6 \%)$, and bulk cold content $\left(\mathrm{R}^{2}=0.90\right.$ and Pbias $\left.=-2.0 \%\right)$. A snow density profile derived by utilizing an empirical formulation also provided reasonable estimates of cold content $\left(\mathrm{R}^{2}=0.42\right.$ and Pbias $\left.=5.17 \%\right)$. Thanks to these encouraging results, the reconstructed and continuous $C C$ series could be analyzed at the four sites, revealing the impact of rain-on-snow and cold air pooling episodes on the variation of $C C$. The continuous multilayer cold content time series also provided us with information about the effect of stand structure, local topography, and meteorological conditions on cold
\end{abstract} 30 content variability. Additionally, a weak relationship between canopy structure and $C C$ was identified.

Keywords: cold content, forest, temperature profile, snow density, snow depth 
https://doi.org/10.5194/tc-2021-98

Preprint. Discussion started: 13 April 2021

(c) Author(s) 2021. CC BY 4.0 License.

(c) (i)

\section{Introduction}

The use of spatially distributed, process-based (physical) hydrological models has substantially improved decision-making in the area of water resources management (Wigmosta et al., 2002). The snow processes included in such models rely on the energy balance (EB) approach, since snow accumulation and melt depend on the exchanges of energy and mass between the snowpack and its surrounding environment (soil, atmosphere, and vegetation). The concept of snowpack energy budget was first introduced by the U.S. Army Corps of Engineers (1956). Since then, the single bulk layer representation (e.g Wigmosta et al., 1994) has evolved into multilayer schemes (Gouttevin et al., 2015; Koivusalo et al., 2001; Lehning et al., 2002; Vionnet et al., 2012). Recent studies have looked at the sources of uncertainty associated with snow models (Essery et al., 2013; Rutter

40 et al., 2009) and revealed the importance of including some key state variables, particularly cold content, in their modelling schemes.

Cold content $(C C)$ is the amount of energy required for a snow cover to reach $0^{\circ} \mathrm{C}$ for its entire depth. Any additional energy input translates into melting. By definition, $C C$ is a linear function of the snow water equivalent (SWE) and snowpack temperature, and is defined by:

$45 C C=c_{i} \rho_{s} H S\left(T_{s}-T_{m}\right)$

where $C C$ is cold content $\left(\mathrm{MJ} \mathrm{m}^{-2}\right), c_{i}$ is the specific heat of ice $\left(2.1 \times 10^{-3} \mathrm{MJ} \mathrm{kg}^{-1}{ }^{\circ} \mathrm{C}^{-1}\right), \rho_{s}$ is the snow density $\left(\mathrm{kg} \mathrm{m}^{-3}\right), \rho_{w}$ is the density of water $\left(\mathrm{kg} \mathrm{m}^{-3}\right), H S$ is the snow depth $(\mathrm{m}), T_{m}$ is the melting temperature $\left(0^{\circ} \mathrm{C}\right)$, and $T_{s}$ is the snowpack temperature $\left({ }^{\circ} \mathrm{C}\right)$. Thus, $C C$ ranges from $-\infty$ to $0 \mathrm{MJ} \mathrm{m}^{-2}$, meaning that the larger the absolute value of $C C$, the more energy required for the snowpack to eventually reach a uniform temperature of $0^{\circ} \mathrm{C}$, over the entire depth of the snowpack.

$C C$ plays a central role in delaying snowmelt (Molotch et al., 2009), as a deep, dense, and cold snowpack requires a substantial amount of energy for snow to reach $0^{\circ} \mathrm{C}$ and initiate melt. As such, understanding $C C$ is essential for the accurate forecasting of water availability in demanding sectors such as agricultural systems, urban water supply (Barnett et al., 2005), and hydropower generation (Schaefli et al., 2007).

The exact determination of $C C$ requires direct observations of the snowpack temperature, density, and depth, usually collected

55 from manual snow surveys. As manual collection is tedious and demanding, few datasets that describe snowpack $C C$ are available. For lack of a better approach, $C C$ is often estimated using one of the following three methods: an empirical formulation that relies solely on air temperature (DeWalle and Rango, 2008; Seligman et al., 2014), an empirical formulation based on air temperature and precipitation (Andreadis et al., 2009; Wigmosta et al., 1994), or a residual from an energy balance model (Marks and Winstral, 2001). Jennings et al. (2018) resorted to snowpit data, collected at alpine and subalpine sites

60 within the Rocky Mountains in Colorado, to study $C C$. They reported a weak relationship between $C C$ and the cumulative mean of air temperature. They also found that newly fallen snow was responsible for $84.4 \%$ and $73.0 \%$ of the daily gains in $C C$ for alpine and subalpine snowpacks, respectively. Of note, a slight contrast was observed by Seligman et al. (2014), who reported that the contribution of spring snow storms to $C C$ had a smaller impact on delaying snowmelt than the porous space from dry fresh snow. However, Jennings et al. (2018) reported shifts in the onset of snowmelt by $5.7 \mathrm{~h}$ and $6.7 \mathrm{~h}$ at alpine and 
65 subalpine sites, respectively, when $C C$ at 6:00AM was less than $0 \mathrm{MJ} \mathrm{m}^{-2}$. This suggests that even a small energy deficit has a substantial effect on the rate and timing of snowmelt. Overall, previous studies agree that the careful consideration of $C C$ improves snowmelt simulations (Jost et al., 2012; Mosier et al., 2016; Valéry et al., 2014).

Little to no previous research has focused on $C C$ behaviour in forested environments. Snowpack energy exchanges within a forest are obviously different than those in open or alpine areas, as the presence of a canopy impacts snow accumulation and melt (Andreadis et al., 2009; Gouttevin et al., 2015; Mahat and Tarboton, 2012; Wigmosta et al., 2002). For instance, intercepted snow may sublimate, undergo densification, or fall beneath the canopy when maximum canopy storage is reached or when there are heavy winds present (DeWalle and Rango, 2008). Snow interception typically leads to shallower snow depths and less melt beneath the canopy (Musselman et al., 2008), even in the presence of rain-on-snow events (Marks et al., 1998). Frequent density profiles of the snow cover allow for the tracking of unloading episodes and the identification of spatial differences of $C C$ within a forest.

Despite all of the associated challenges, it is possible to simulate snow in a forested environment with some success. For instance, physically-based land surface models are regularly used to simulate snow at forested sites (e.g., Roy et al., 2013). One such example is the Canadian LAnd Surface Scheme (CLASS), which relies on a single-layer snow model articulated around the energy balance. In a recent study, Alves et al.(2020) used CLASS driven by ERA5 reanalysis data to model snow

80 depths from four dissimilar forested sites across the Canadian boreal biome. They reported average snow persistence lengths and average spring melting periods that were similar to our field observations. By definition, CLASS considers the whole snowpack as a single bulk unit, and as such, is unable to simulate the multilayer behaviours that one sees in nature. One option for addressing this is to resort to a multilayer snow model such as SNOWPACK (Lehning et al. 2001), which was recently equipped with a thorough canopy module (Gouttevin et al., 2015); however, even models such as this are not free of biases.

85 Alternatively, bulk snowpack values can be distributed between several layers. For instance, Roy et al. (2013) disaggregated CLASS-derived snow water equivalents into multilayer values at each time step, for the purpose of estimating the specific surface area (SSA) of a snowpack. They attained an acceptable root mean square error (RMSE) of $8.0 \mathrm{~m}^{2} \mathrm{~kg}^{-1}$ in CLASSderived SSA for individual layers.

In view of the obvious lack of observational studies that are required to support model development in forested environments,

90 detailed analyses of multilayer in situ snowpack $C C$ are necessary. Building on Jennings et al. (2018), this study investigates 53 snowpit-derived $C C$ observations at four distinct coniferous forested sites, over the course of one winter. The temporal variability of the $C C$ is also analysed by reconstructing time series that include bulk and multilayer $C C$ with a 30-min time step, and combine automated snow temperature observations and bulk snow density estimates that was calculated using the CLASS model. 
https://doi.org/10.5194/tc-2021-98

Preprint. Discussion started: 13 April 2021

(c) Author(s) 2021. CC BY 4.0 License.

\section{Methods}

\subsection{Study sites and data collection}

Observations were collected in the Bassin Expérimental du Ruisseau des Eaux-Volées (BEREV), which is a small boreal forest catchment within Montmorency Forest, Quebec, Canada (Fig. 1). This region experiences substantial precipitation (1583 mm), with 40\% falling in solid form between November and May (Isabelle et al., 2018). The boreal catchment lies in the Laurentian Mountains of the Canadian Shield and is characterized by a humid continental climate (Schilling et al., 2021). There are patches of forest clearings found within the basin due to past logging operations that have led to variability in stand structure (Parajuli et al., 2020b).

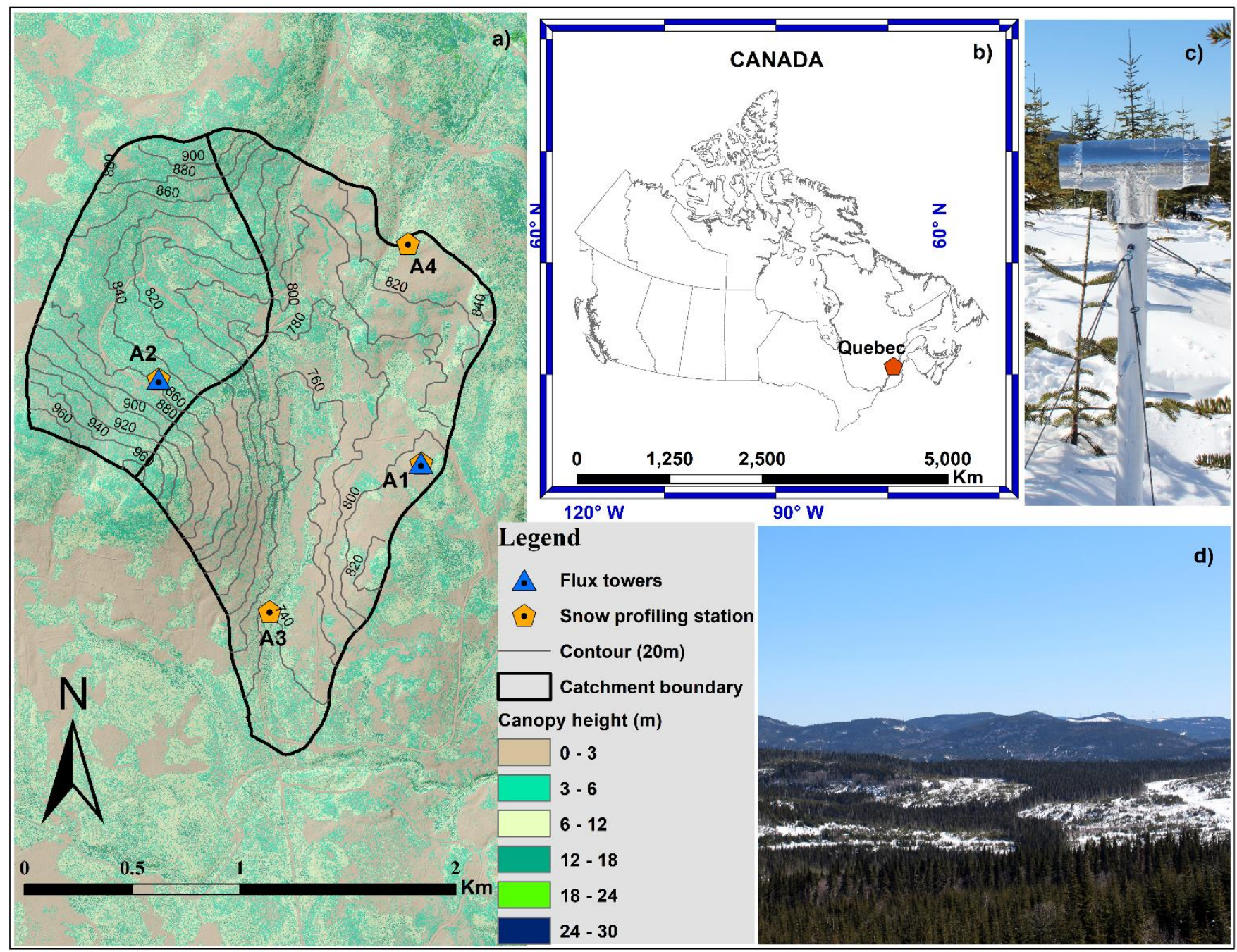

Figure 1. Overview of the study area. (a) Basin 7 within BEREV showing the locations of the four study sites (A1 to A4), where snowpit samples were collected and snow-profiling stations were installed, (b) the location of BEREV in eastern Canada, (c) the snow profiling station installed at site A1, and (d) typical winter conditions at BEREV as seen from the flux tower at site A2. 
https://doi.org/10.5194/tc-2021-98

Preprint. Discussion started: 13 April 2021

(c) Author(s) 2021. CC BY 4.0 License.

(c) (i)

Over the years, several vegetation species such as black spruce (Picea mariana (Mill.)) and white spruce (Picea glauca (Moench.)) were planted. However, the environment favoured the regrowth of balsam fir (Abies balsamea) stands. Isabelle et al. (2020) provide detailed information on the vegetation cover at the study site. The current analysis focuses on the four 110 contrasting sites presented in Table 1.

Inspired by Lundquist and Lott (2010), we deployed an automated snow-profiling station at each location, composed of 18 Ttype thermocouples vertically spaced $10 \mathrm{~cm}$ apart and of an ultrasonic depth sensor (Judd Communication, USA). An additional T-type thermocouple was enclosed in a radiation shield (Fig.1c) $2 \mathrm{~m}$ above ground for simultaneous air temperature measurements.

115 Table 1. General canopy characteristics at the four experimental sites.

\begin{tabular}{ccccc}
\hline Site & $\begin{array}{c}\text { Mean tree height } \\
(\mathbf{m})\end{array}$ & $\begin{array}{c}\text { Canopy density } \\
\text { (fraction) }\end{array}$ & $\begin{array}{c}\text { LAI } \\
\left(\mathbf{m}^{\mathbf{2}} \mathbf{~ m}^{-\mathbf{2}}\right)\end{array}$ & Forest cover \\
\hline A1 & 1.8 & 0.76 & 2.8 & sapling \\
A2 & 8.1 & 0.76 & 3.4 & juvenile \\
A3 & 8.6 & 0.97 & 3.5 & mature \\
A4 & 12.5 & 0.71 & 2.3 & mature \\
\hline
\end{tabular}

Snowpit samples (temperature profile, depth, and density) were collected in the vicinity of the snow-profiling stations on a weekly basis from 17 January 2018 to 24 May 2018 ( $\approx 60 \%$ of the snow cover period), enabling CC calculation following Eq.1. Maintaining a weekly timeline was sometimes difficult due to uncontrollable circumstances such as freezing rain, rain-onsnow events or even winter storms. During melt, from 21 April 2018 and on, it was impossible to reach all study sites because of reduced snow depths preventing the safe use of snowmobiles, except for site A2 that was more easily accessible from the main road. Snow-profiling stations malfunctioned occasionally (less than 1\% of the time), mostly in spring. Missing values were filled with snowpit observations. An exponential moving average procedure was implemented to reduce noise in snow depth observations.

\subsection{Construction of $C C$ time series}

The exercise of constructing 30-minute time series of the snowpack $C C$ represents a certain challenge. On the one hand, it requires time series of the vertical profile of snow temperature, which is obtained from the snow-profiling stations. On the other hand, time series of the snow density profile are needed as well. This is where the main difficulty lies. A simple approach would be to interpolate the density values extracted from snowpits, but this would be incomplete and error-prone given their

130 limited number and absence early in the season. Herein, it was opted to produce multilayer time series of snow density thanks to CLASS bulk simulations complemented with empirical formulations, as detailed below. 
https://doi.org/10.5194/tc-2021-98

Preprint. Discussion started: 13 April 2021

(c) Author(s) 2021. CC BY 4.0 License.

(c) (i)

\subsubsection{CLASS model}

CLASS is a physically-based land surface model that simulates the exchanges of water and energy between the Earth's surface and the atmosphere (Bartlett et al., 2006; Verseghy, 1991). It considers four distinct surface subareas: bare soil, canopy cover over bare soil, canopy with snow cover, and snow cover over bare soil (Bartlett and Verseghy, 2015; Verseghy et al., 2017). In this analysis, CLASS version 3.6 was used in offline mode and with a 30-min time step, enabling the stability of the prognostic modelled variables (Roy et al., 2013). CLASS allows for the inclusion of multiple soil layers and accounts for snow interception, snow thermal conductivity, and snow albedo, as described in Bartlett et al. (2006). The following subsections describe the meteorological forcing data required to run CLASS, and the methodology (CLASS + snow-profiling station) to produce single- and multi-layer time series of snow density, following Andreadis et al. (2009).

\subsubsection{CLASS setup and forcing}

The meteorological inputs required to run CLASS include precipitation rate, wind speed, air specific humidity, incoming shortwave and longwave radiation, air temperature, and surface atmospheric pressure (Alves et al., 2019; Leonardini et al., 2020). As CLASS is designed to explicitly consider the energy exchanges between the soil surface, vegetation, snowpack, and

145 atmosphere, above-canopy meteorological forcings are used. The model accounts for local effects associated with the presence of a canopy (e.g., attenuation of incident radiation, etc.), and incorporates user-defined parameters such as vegetation height, canopy density, and leaf area index (Table 2).

Table 2. Local availability of meteorological forcing data for use in CLASS simulations.

\begin{tabular}{|c|c|c|c|c|}
\hline Inputs & Site A1 & Site A2 & Site A3 & Site A4 \\
\hline \multicolumn{5}{|l|}{ Meteorological inputs } \\
\hline Precipitation rate & $x$ & $x$ & $x$ & $x$ \\
\hline Incoming shortwave radiation & $x$ & $x$ & & \\
\hline Incoming longwave radiation & $x$ & $x$ & & \\
\hline Air temperature & $x$ & $x$ & $x$ & $x$ \\
\hline Surface atmospheric pressure & $x$ & $x$ & & \\
\hline Wind speed & $x$ & $x$ & & \\
\hline Air specific humidity & $x$ & $x$ & & \\
\hline \multicolumn{5}{|l|}{ Vegetation information } \\
\hline Leaf area index (LAI) & $x$ & $x$ & $x$ & $x$ \\
\hline Canopy height & $x$ & $x$ & $x$ & $x$ \\
\hline Canopy density & $x$ & $x$ & $x$ & $x$ \\
\hline
\end{tabular}


Precipitation rates were determined using a GEONOR weighting gauge equipped with a single Alter shield approximately 4 $\mathrm{km}$ north of the study area, and were considered to be uniformly distributed throughout the catchment. Given the known windinduced bias associated with this type of gauge (Pierre et al., 2019), a simple adjustment was applied. This adjustment involved twice-daily manual precipitation observations from a Double Fence Intercomparison Reference (DFIR) setup close by, as in Parajuli et al. (2020a). Vegetation parameters were extracted at each site from a LiDAR dataset. Wind speed, air specific humidity, shortwave and longwave radiation, and surface atmospheric pressure measurements were taken from flux towers at sites A1 and A2. Comparable data were unavailable at sites A3 and A4 (Table 2).

This study was carried out in a small experimental watershed with an area of $3.49 \mathrm{~km}^{2}$, where the sampling sites (A1 to A4) were close to one another (Fig.1) but had distinct characteristics (Table 1). Given the similarity (more or less) in canopy structure, we opted to use the inputs recorded at site A2 to run CLASS simulations at sites that lacked direct measurements of meteorological inputs (Table 2). Here we assumed negligible differences in the above-canopy inputs between sites A2, A3 and A4. The following sub-section highlights the steps adopted to generate the multilayer density estimates needed to calculate the CC time series for all snow layers.

\section{2.2.3 Reconstruction of multilayer snow density time series (a hybrid approach)}

The empirical formulation described in Andreadis et al. (2009), based on Anderson (1976), is used to reconstruct multiple layer snow density estimates by combining the CLASS-derived snow water equivalent (SWE) estimates (hereafter referred to as the hybrid procedure). Fresh snow density follows the formulation from Brun et al. (1989), who developed the method using data collected in the French Alps. We initialized the density of fresh snow by imposing a minimum snow density of $76 \mathrm{~kg} \mathrm{~m}^{-}$

$170{ }^{3}$, based on available snowpit observations, and then using the equation:

$\rho_{f}=\max \left[\left(109+6\left(T_{a}-273.16\right)+26 \sqrt{u_{m}}\right), 76\right]$

where $\rho_{f}$ is the density of fresh snow $\left(\mathrm{kg} \mathrm{m}^{-3}\right), u_{m}$ is the wind speed $\left(\mathrm{m} \mathrm{s}^{-1}\right)$, and $T_{a}$ is the air temperature $(\mathrm{K})$. With the exception of Eq 2, both $T_{a}$ and $T_{s}$ are presented in degrees Celsius $\left({ }^{\circ} \mathrm{C}\right)$. As snow undergoes compaction due to metamorphism and the increasing weight of overlying snow, density is assumed to increase according to the following rate:

$175 \quad \frac{\Delta \rho_{s}}{\Delta t}=\left(C R_{m}+C R_{o}\right) \rho_{s}$

where $t$ is time (s), $C R_{m}$ is the snow compaction due to metamorphism $\left(\mathrm{kg} \mathrm{m}^{-3} \mathrm{~s}^{-1}\right)$, and $C R_{o}$ is the compaction due to the weight of overlying snow $\left(\mathrm{kg} \mathrm{m}^{-3} \mathrm{~s}^{-1}\right) . C R_{m}$ is then calculated as (Andreadis et al., 2009):

$C R_{m}=2.778 \times 10^{-6} c_{3} C_{4} e^{-0.04 \times\left(273.15-T_{S}\right)}$ 
https://doi.org/10.5194/tc-2021-98

Preprint. Discussion started: 13 April 2021

(c) Author(s) 2021. CC BY 4.0 License.

(c) (i)

$\left\{\begin{array}{lr}c_{3}=c_{4}=1 & \rho_{s} \leq 150 \mathrm{~kg} \mathrm{~m}^{-3} \\ c_{3}=e^{-0.046\left(\rho_{s}-150\right)} & \text { if } \rho_{s}>150 \mathrm{~kg} \mathrm{~m}^{-3} \\ c_{4}=2 & \rho_{s}>150 \mathrm{~kg} \mathrm{~m}^{-3}\end{array}\right.$

180 and $C R_{o}$ is calculated as (Andreadis et al. 2009):

$C R_{o}=\frac{P_{S}}{n_{0}} \times e^{-c_{5}\left(273.15-T_{S}\right)} e^{-c_{6} \rho_{S}}$

where $n_{0}=3.6 \times 10^{-6} \mathrm{~N} \mathrm{~s} \mathrm{~m}^{-2}$ is the snow viscosity, $c_{5}=0.08 \mathrm{~K}^{-1}, c_{6}=0.021 \mathrm{~m}^{3} \mathrm{~kg}^{-1}$ and $P_{s}\left(\mathrm{~N} \mathrm{~s} \mathrm{~m}^{-2}\right)$ is the load pressure for each layer. The load pressure is defined as:

$P_{s}=\frac{1}{2} g \rho_{w}\left(W_{n s}+f W_{s}\right)$

185 where $g$ is the acceleration due to gravity $9.8 \mathrm{~m} \mathrm{~s}^{-2}, W_{n s}$ and $W_{s}$ are the amount of new snow and the snow (derived from CLASS) within the snowpack layer (mm w.e.), respectively, and $f$ is the empirical compaction coefficient taken as 0.6 (Andreadis et al., 2009).

\section{Results}

\subsection{Local meteorological conditions}

190 Figure 2 displays daily air temperature and wind speed observations. The shaded zone and site-specific dots illustrate the temporal distribution of the manual snow surveys. Air temperature measurements were taken at $2 \mathrm{~m}$ above ground. Wind speed sensors were located $3 \mathrm{~m}$ and $2 \mathrm{~m}$ above ground at sites A1 and A2, respectively. To compensate for this height difference and enable fair comparisons between sites A1 and A2, wind speed measurements at site A1 were adjusted to a 2-m height, assuming a $\log$ profile. As expected, the sapling site (mean canopy of $1.8 \mathrm{~m}$ ) experienced higher wind speeds (mean $1.3 \mathrm{~m} \mathrm{~s}^{-1}$ ) than the juvenile one (mean canopy of $8.1 \mathrm{~m}$ and mean wind speed of $0.12 \mathrm{~m} \mathrm{~s}^{-1}$ ). Air temperatures were homogenous from site to site, with average values of $-6.1^{\circ} \mathrm{C},-6.3{ }^{\circ} \mathrm{C},-6.9^{\circ} \mathrm{C}$, and $-6.5^{\circ} \mathrm{C}$ at sites $\mathrm{A} 1, \mathrm{~A} 2, \mathrm{~A} 3$, and $\mathrm{A} 4$, respectively. 


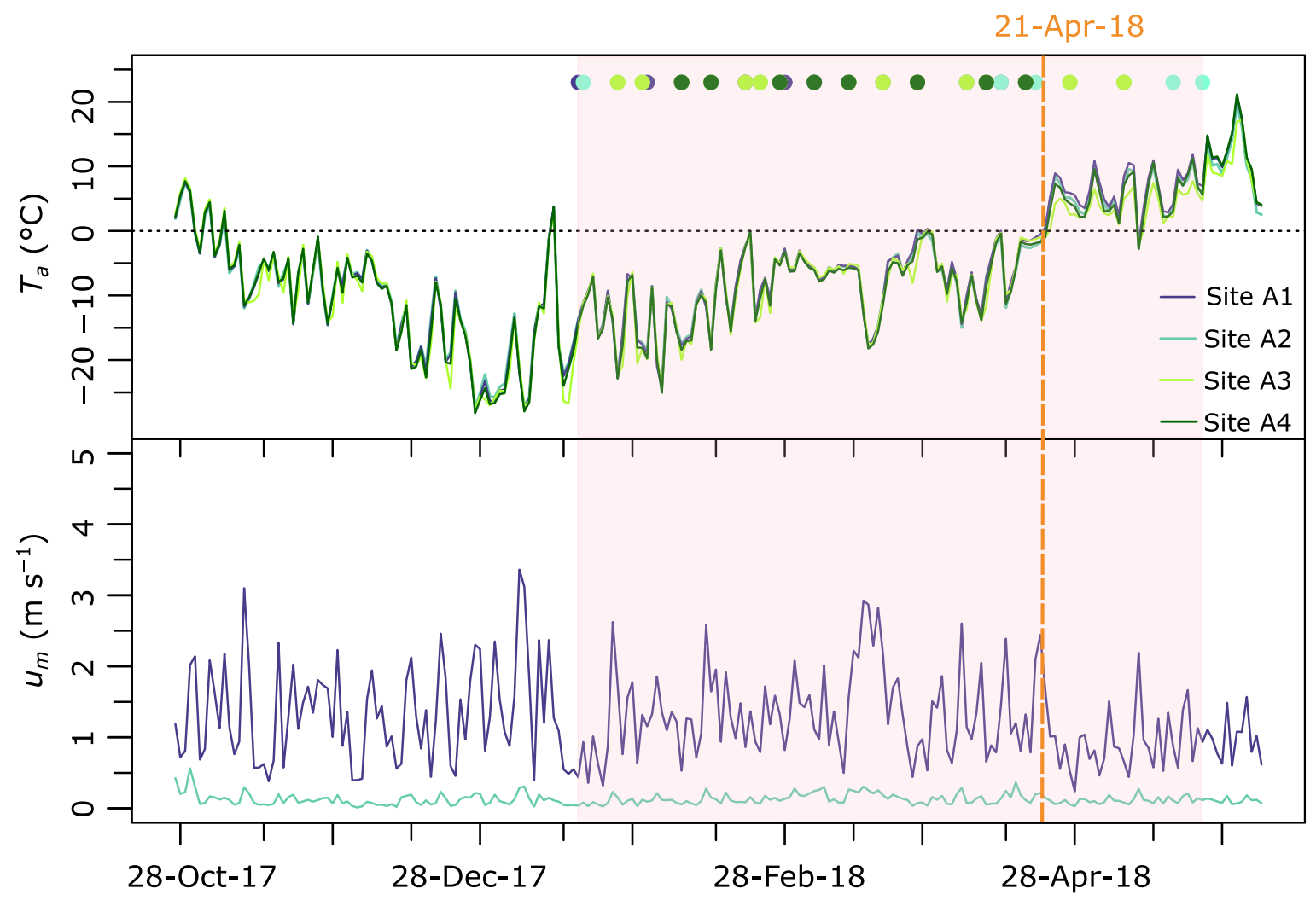

Figure 2. (a) Daily 2-m air temperature ( $\left.T_{a}\right)$ observations for all the study sites. (b) Daily 2-m wind speed $\left(u_{m}\right)$ for sites A1 (sapling) and $\mathrm{A} 2$ (juvenile). The shaded region indicates the extensive snowpit measurement period. Coloured dots illustrate specific snowpit surveys. Spring melt started on 21 April 2018.

\subsection{Cold content observations from snowpit surveys}

Figure 3 illustrates 10-cm $C C$ derived from the snowpit surveys. One has to sum up all the values of a single profile to find

the total $C C$ for a specific date. Variability in snow depth, mainly induced by contrasting canopy structure, is indicated in Figure 3. When comparing layer-wise $(10 \mathrm{~cm})$ differences (A1, A2, A3, and A4), the lowest $\left(-0.013 \mathrm{MJ} \mathrm{m}^{-2}\right)$ and peak $(-0.67$ $\mathrm{MJ} \mathrm{m}^{-2}$ ) $C C$ both occurred at site $\mathrm{A} 2$. Unlike for spring melt, when $C C$ is low and relatively uniform, the accumulation period portrays substantial layer-wise variability structured around three distinct layers. For instance, sites A1, A2, A3, and A4 reported $9,15,12$, and 5 observations of $C C$ that were below $-0.35 \mathrm{MJ} \mathrm{m}^{-2}$. Note that the occurrence of large amplitude of $C C$ values was not always confined to the topmost layer, as the layer just beneath the top layer also exhibited such amplitude (see Fig. 3, week 10, site A3 at a snow depth of $106 \mathrm{~cm}$, for example). However, the layers that are close to the ground experienced smaller amplitude of $C C$ throughout the winter. Peak $C C$ occurred in early February (Fig. 4 and Table 3), when the minimum daily air temperature fell to about $-25^{\circ} \mathrm{C}$ (Fig. 2). At that time, the amplitude of $C C$ was highest at site A1, which also had the deepest snowpack $(128 \mathrm{~cm})$. The total $C C$ time series highlighted the variability of $C C$ across the four study sites (Fig. 4). 
https://doi.org/10.5194/tc-2021-98

Preprint. Discussion started: 13 April 2021

(c) Author(s) 2021. CC BY 4.0 License.

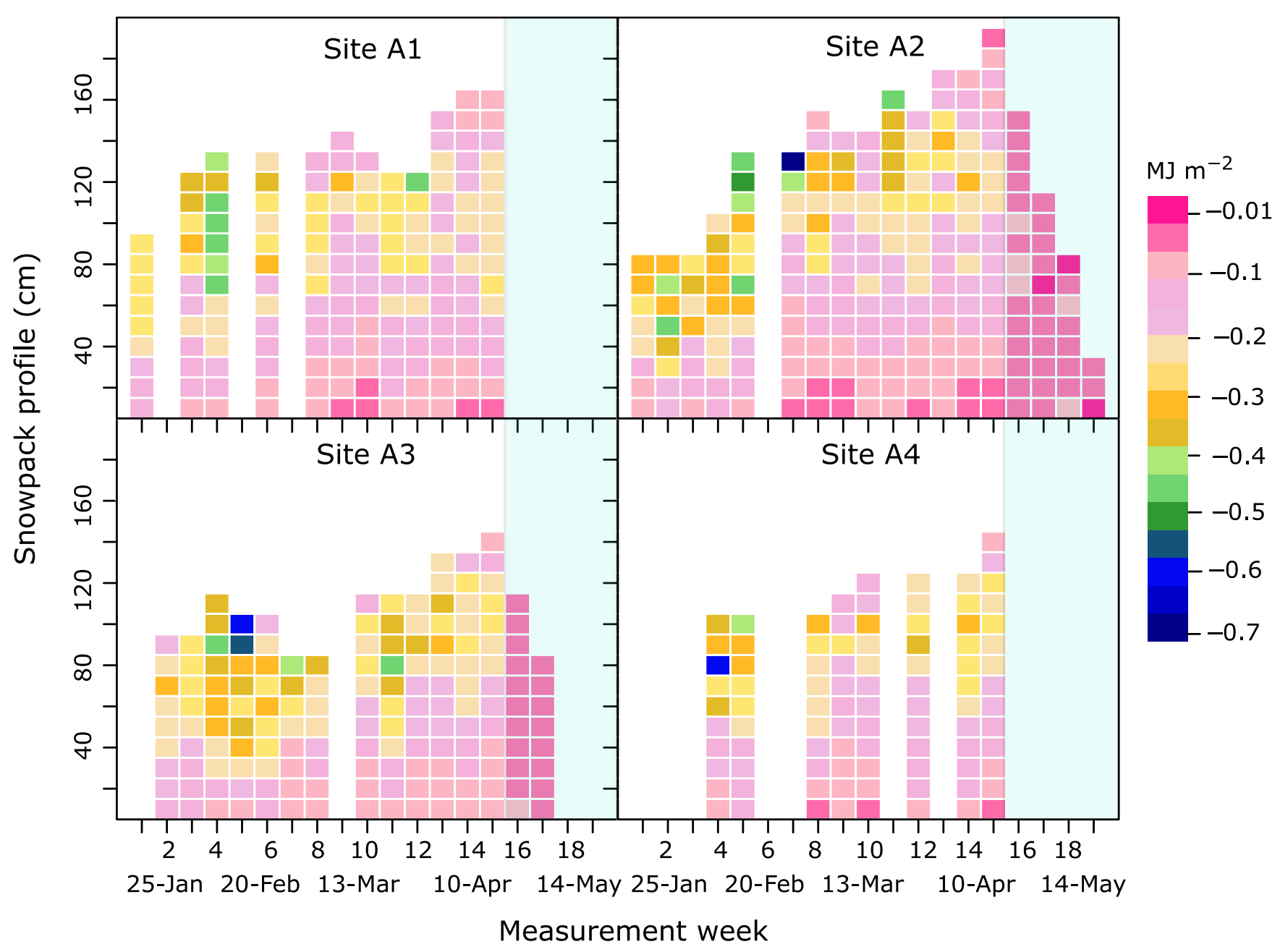

Figure 3. Weekly 10-cm $C C$ observations from snowpit surveys. The light blue shading indicates active spring melt. The colour bar indicates $C C$ values in $\mathrm{MJ} \mathrm{m}^{-2}$

Overall, maximum snow depth occurred at site A2 $(194 \mathrm{~cm})$, which also experienced the largest amplitude of mean total $C C$ $\left(-2.62 \mathrm{MJ} \mathrm{m}^{-2}\right)$, as a thicker snowpack can hold more $C C$ (Table 3). For its part, A4 experienced the smallest maximum snow depth $(142 \mathrm{~cm})$ and the lowest amplitude of mean total $C C\left(-2.15 \mathrm{MJ} \mathrm{m}^{-2}\right)$. The $C C$ difference across sites reached $0.47 \mathrm{MJ}$ $\mathrm{m}^{-2}$ in total cold content, representing a variability of $20 \%$. 


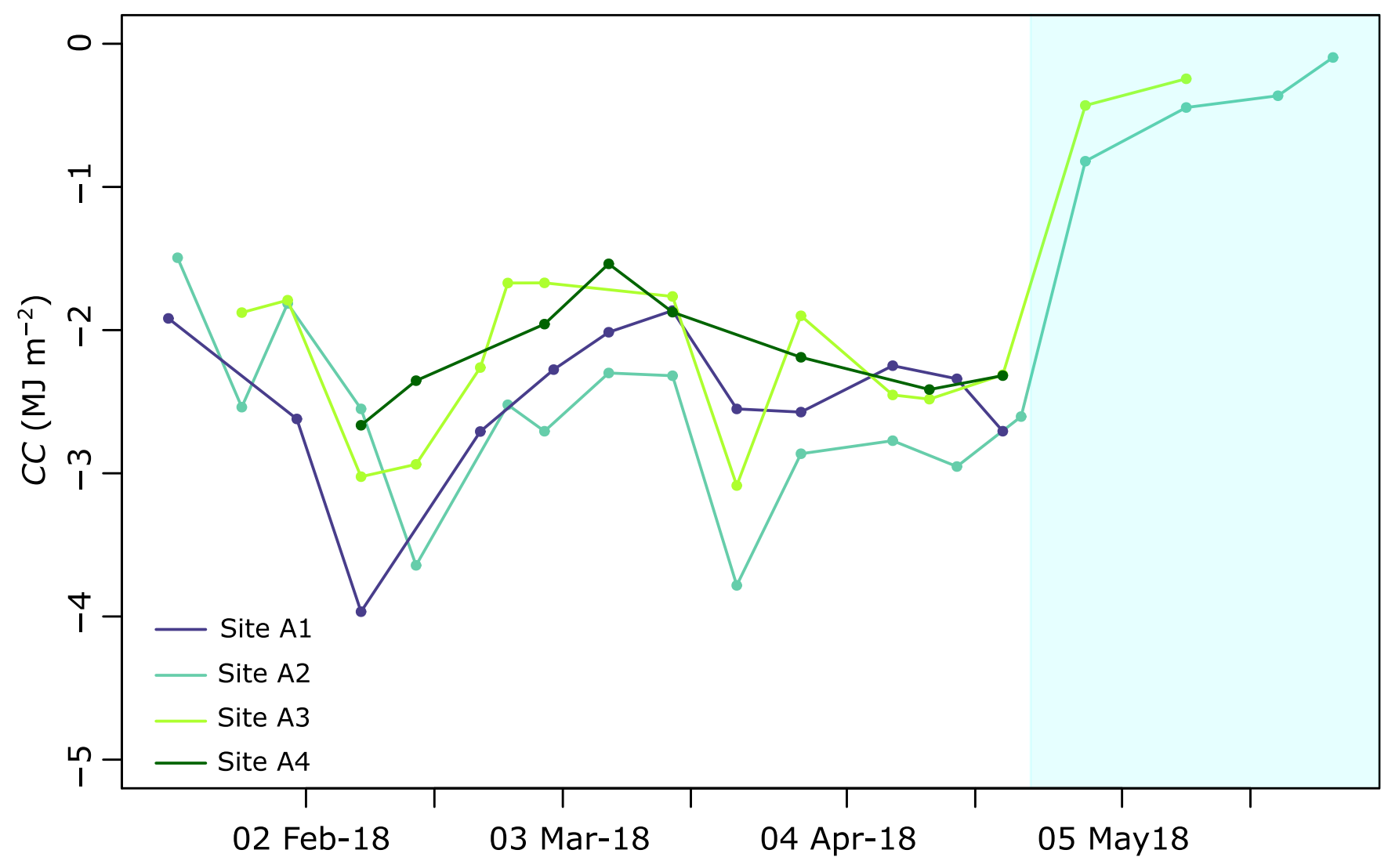

Figure 4. Weekly snowpack total $C C$ from snowpit surveys. The light blue shading represents active spring melt.

Table 3. Peak total $C C$, date of occurrence, snow depth, mean tree height at the site, maximum snow depth, and mean total $C C$ over a period of 15 weeks.

\begin{tabular}{ccccccc}
\hline Sites & $\begin{array}{c}\text { Peak total } \\
C C\end{array}$ & $\begin{array}{c}\text { Date of } \\
\text { occurrence of } \\
\left(\mathrm{MJ} \mathrm{m}^{-2}\right)\end{array}$ & $\begin{array}{c}\text { Snow depth } \\
\text { at peak total } \\
C C(\mathrm{~cm})\end{array}$ & $\begin{array}{c}\text { Tree height } \\
(\mathrm{m})\end{array}$ & $\begin{array}{c}\text { Maximum } \\
\text { snow depth } \\
(\mathrm{cm})\end{array}$ & $\begin{array}{c}\text { Mean total } \\
C C\left(\mathrm{MJ} \mathrm{m}^{-2}\right)\end{array}$ \\
\hline A1 & -4.05 & $2018-02-07$ & 128 & 1.8 & 163 & -2.45 \\
A2 & -3.77 & $2018-02-13$ & 127 & 8.1 & 194 & -2.62 \\
A3 & -3.24 & $2018-02-13$ & 95 & 8.6 & 143 & -2.26 \\
A4 & -2.66 & $2018-02-07$ & 100 & 12.5 & 142 & -2.15 \\
\hline
\end{tabular}


https://doi.org/10.5194/tc-2021-98

Preprint. Discussion started: 13 April 2021

(c) Author(s) 2021. CC BY 4.0 License.

(c) (i)

\subsection{Analysis of reconstructed $C C$ time series}

\subsubsection{Snow density modelling}

A comparison of CLASS snow simulations and snowpit (manual) observations reveals that CLASS is very successful at simulating bulk snow density (Fig. 5; $\mathrm{R}^{2}=0.71$, Pbias $=1.6 \%$ ), $\mathrm{SWE}\left(\mathrm{R}^{2}=0.64\right.$, Pbias $\left.=-17.1 \%\right)$, and $C C\left(\mathrm{R}^{2}=0.90\right.$, Pbias $=-2.0 \%)$.
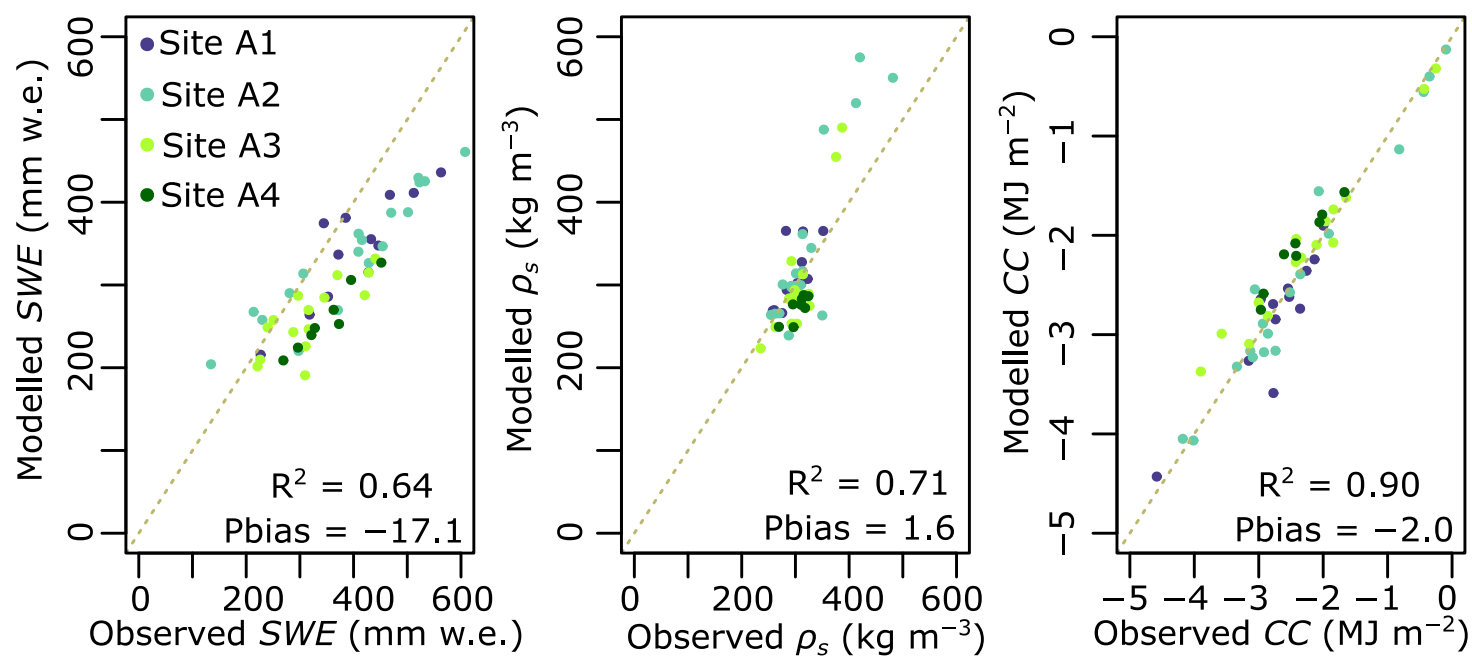

Figure 5. Observed versus CLASS-simulated bulk values of SWE, snow density, and $C C$. $\mathbf{R}^{2}$ denotes the coefficient of determination and Pbias (\%) represents the percent bias.

After confirming that CLASS successfully models bulk snow cover variables, we moved forward with the next step in our methodolgy. We adopted a "hybrid procedure" in which we reproduced a vertical structure following Andreadis et al. (2009).

We compared layer-by-layer, simulated and observed $C C$ and snow density (Fig. 6) and determined that on average (when all sites are considered), the empirical density and observed snow temperature yielded reasonable $C C$ estimates $\left(\mathrm{R}^{2}=0.42\right.$ and Pbias $=-18.5 \%)$. At each site, reasonable $C C$ values were achieved over the entire profile $\left(\mathrm{R}^{2}=0.51 .0 .40 .0 .51\right.$, and 0.19 and Pbias $=-13.3 \%,-18.4 \%,-20.6 \%$, and $-24.1 \%$ at sites A1, A2, A3, and A4, respectively) (Fig. 7).

$C C$ s for the top layer were more difficult to simulate $\left(\mathrm{R}^{2}=0.36,0.29,0.45\right.$, and 0.03$)$ than for the other two layers. Bottomlayer simulations were the most successful $\left(R^{2}=0.85,0.88,0.90\right.$, and 0.86$)$. Density simulations over the entire profile behaved similarly $\left(\mathrm{R}^{2}=0.48\right.$. 0.46. 0.50, and 0.35 and Pbias $=-6 \%,-8.8 \%,-12.3 \%$, and $-13.5 \%$ at sites A1, A2, A3, and A4, respectively). The performance of density simulations, for each layer examined individually, was much less successful, mostly for the top layer $\left(\mathrm{R}^{2}=0.06,0.32,0.32\right.$, and 0.02 and Pbias $=-32.4 \%,-33.7 \%,-35.1 \%$, and $-46.6 \%$ for sites A1, A2, A3, and A4, respectively). However, snow density estimates had a low impact on $C C$ performance, as described previously. These results were deemed sufficient for moving forward with the fine-scale temporal analysis of the reconstructed $C C$. 

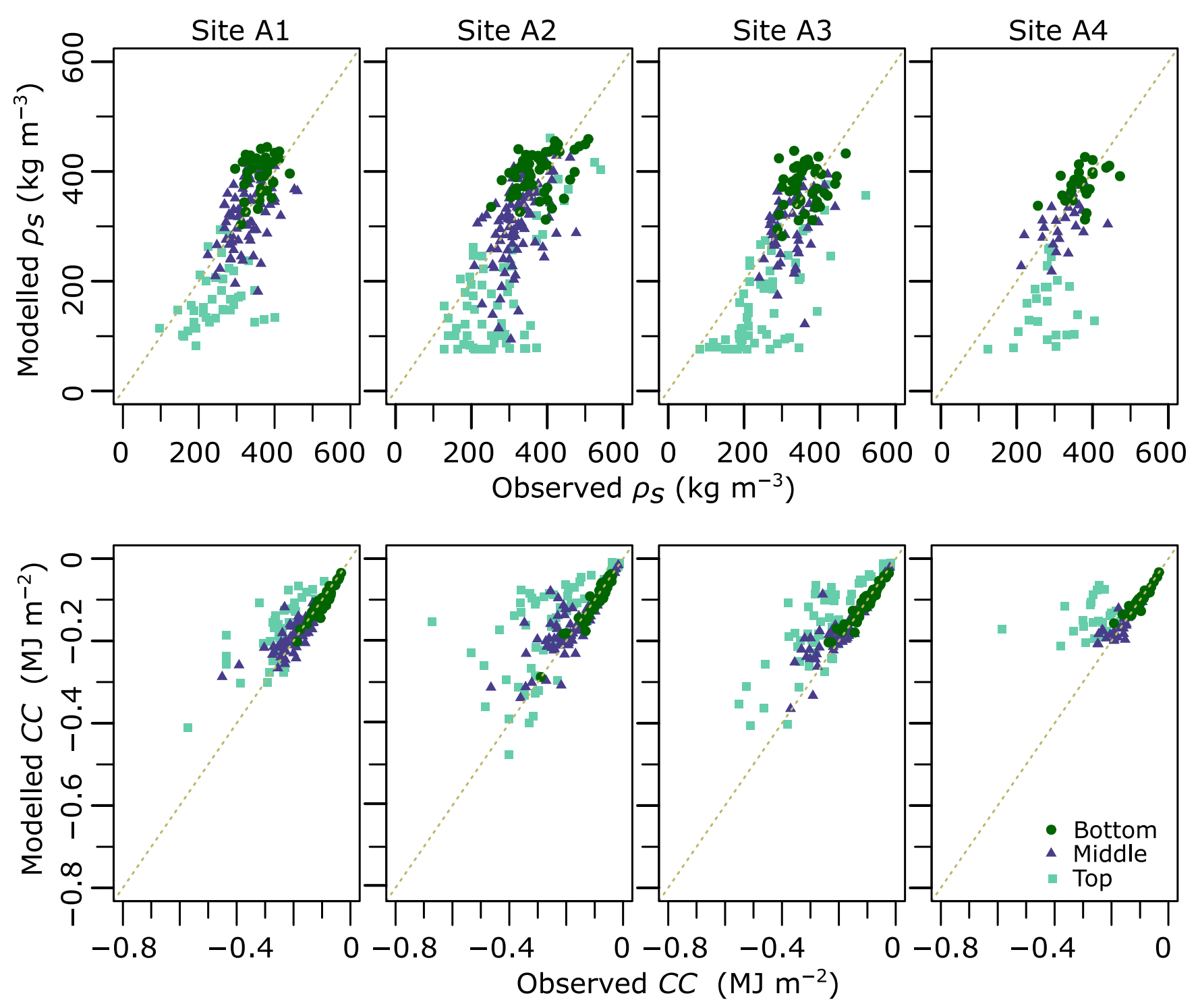

Figure 6. Observed versus modelled snow density and $C C$ derived from the empirical formulation described in subsection 2.2 .3 (remainder). 


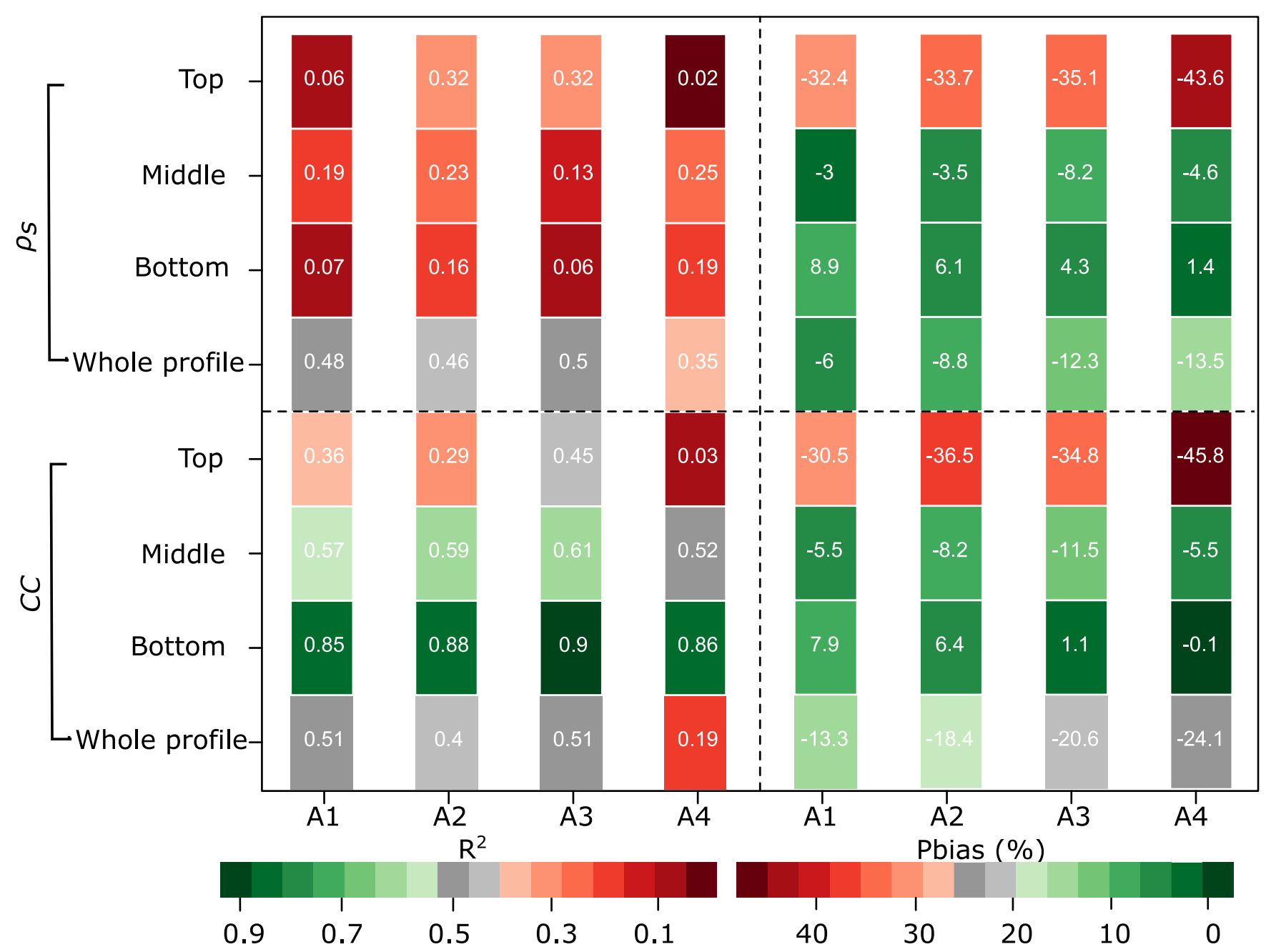

Figure 7. Performance of $C C$ and density simulations following the adopted hybrid procedure, coefficient of determination $\left(R^{2}\right.$, left) and percent bias (Pbias, right). Pbias colour bar applies to both positive and negative values.

\subsubsection{Reconstructed CC time series}

Figure 8 illustrates reconstructed multilayer 30-min CC time series. Although larger peaks ( $-6.9 \mathrm{MJ} \mathrm{m}^{-2}$ for site A1) and smaller average values ( $-1.8 \mathrm{MJ} \mathrm{m}^{-2}$ for site A2) are observed, the high-resolution $C C$ time series that were derived using the hybrid procedure followed a pattern similar to the $C C$ observations presented in section 3.3.1 (Fig. 8, Fig. 9a, and Table 2). Additionally, sites with less vegetation (site A1) experienced higher peak CC than sites with mature forest (A4) (Fig. 8). Notably, the rain-on-snow episodes that occurred on 11 January, 20 February, and 30 March 2018 (thin vertical bands of low $C C)$ were absent from the weekly series shown in Figure 3. Sites A1, A3 and A4 had a shallower snowpack and the rainfall penetrated deeper, resulting in a reduced $C C$ throughout the snowpack. Contrarily, at site A2 which had a deeper snowpack, similar rain penetration into the snowpack was only observed on 11 January 2018. All snowpacks became isothermal from 21 
April 2018 onwards, indicating the onset of spring melt. Some cold spells during spring melt were also noticeable, especially for the shallower snowpacks (A1, A3 and A4).

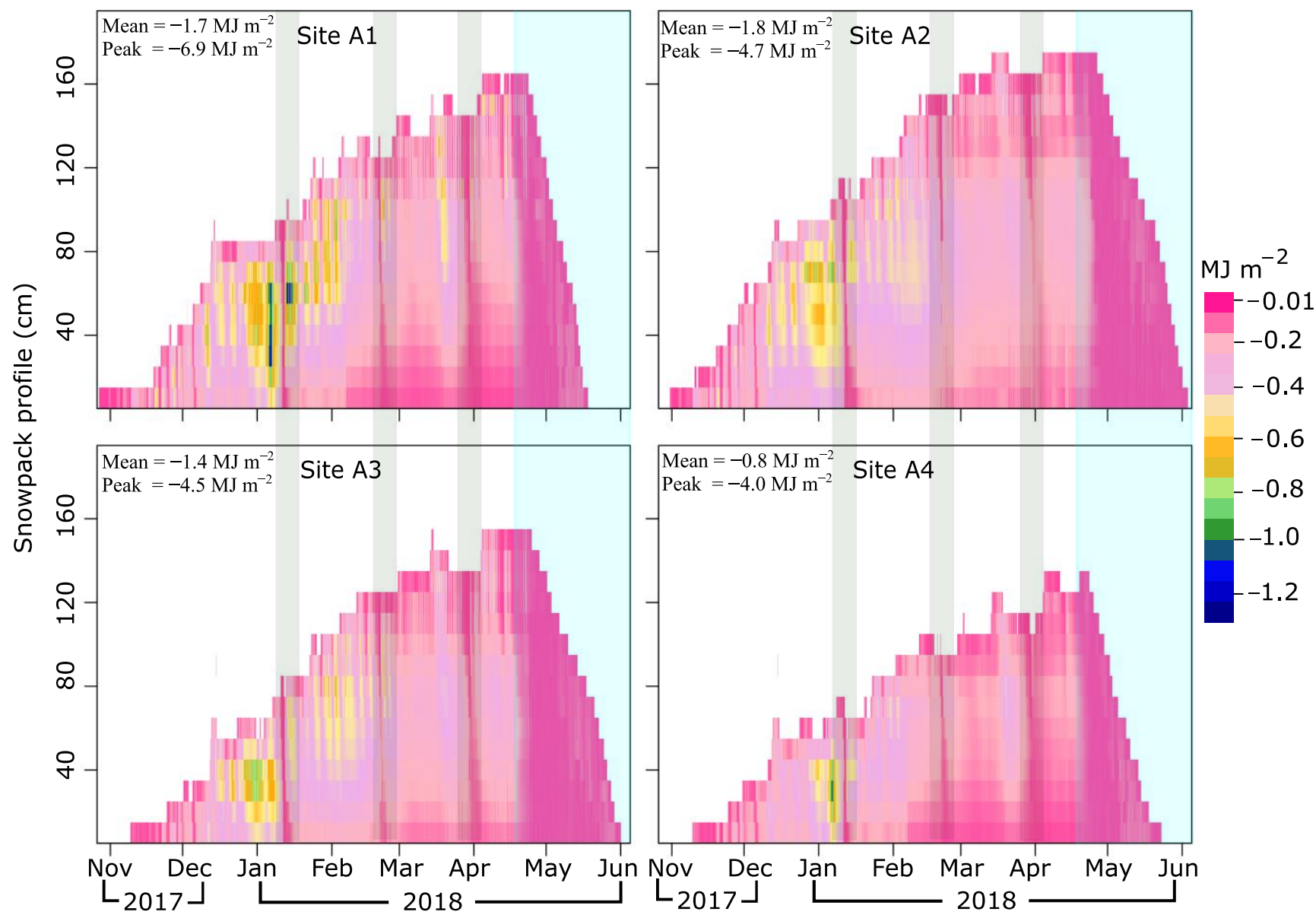

Figure 8. Seasonal variability of $10-\mathrm{cm} C C$ simulations stored at 30 -min time intervals. The colour bar indicates $C C$ values in $\mathrm{MJ}$ $\mathrm{m}^{-2}$. Light green shading represents rain-on-snow events and light blue shading represents melt.

Due to differences in snow accumulation and melt patterns, mostly induced by differences in vegetation and topographic characteristics, there is noticeable site-to-site variability in $C C$ (Fig. 8). The detailed variability of total $C C$ across the four forested sites is presented in Figure 9, along with snow depth. The amplitude of total $C C$ at site A2 was larger than at A1 approximately $60 \%$ of the time. At site A3, this fraction drops to $32 \%$. 

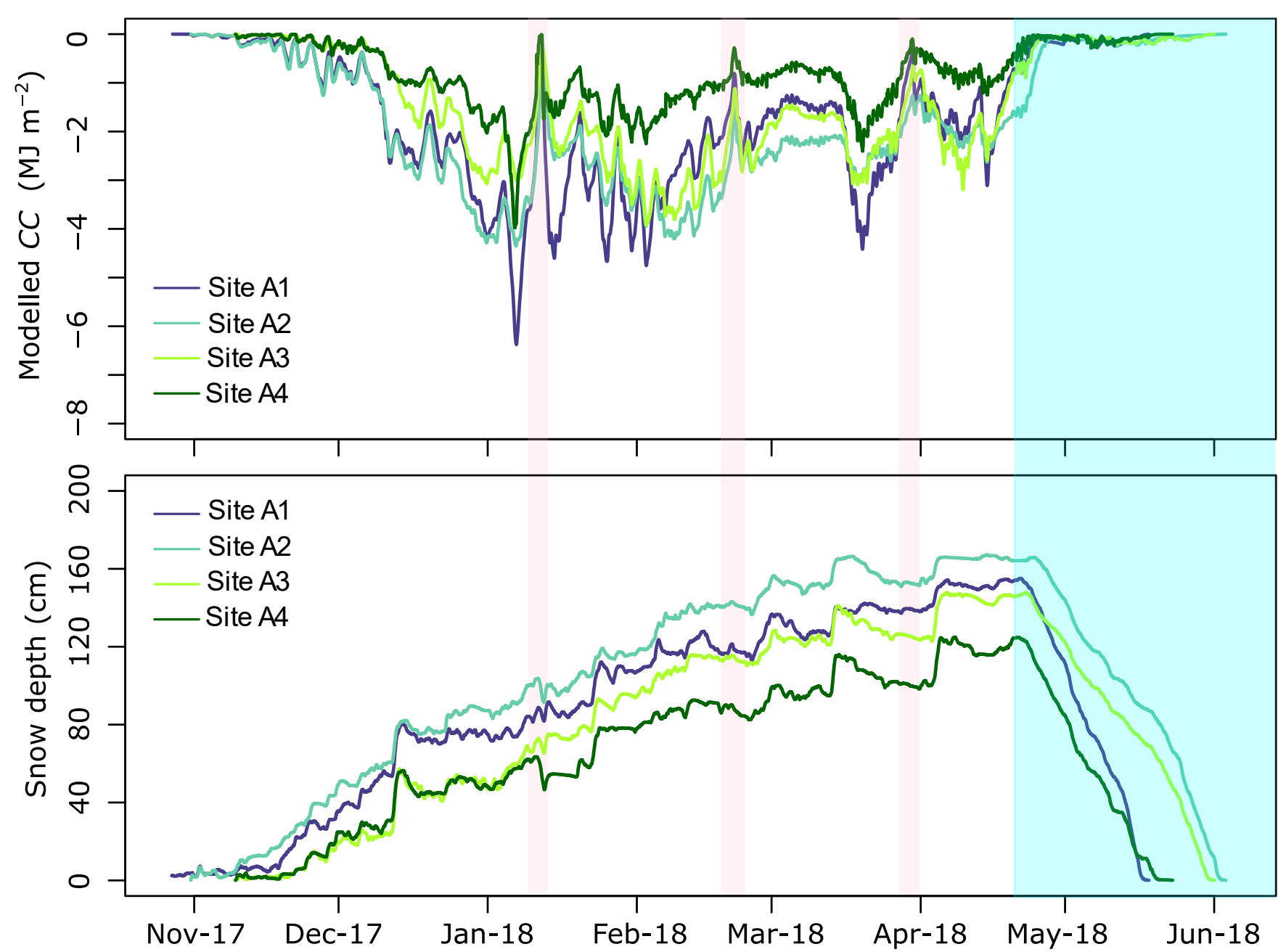

Figure 9. (a) Total estimated $C C$ from the reconstructed time series. An exponential moving average was applied for noise removal. (b) Snow depth observations. Spring melt period and rain-on-snow events are highlighted with light blue and light pink color, respectively.

We examined the relationship between $C C$ and the snow density $\left(\rho_{\mathrm{s}}\right)$, snow depth $(H S)$, snowpack temperature $\left(T_{s}\right)$, and air temperature ( $T_{a}$; Fig. 10). Pearson's correlation coefficient $(r)$ was used to determine these relationships for the observed and estimated values, respectively. Snowpack temperature $(r=0.83$ and 0.69$)$ and air temperature $(r=0.56$, and 0.66$)$ exhibited a positive correlation. Conversely, snow depth $(r=-0.5$ and -0.45$)$ exhibited a negative correlation, whereas snow density $(r=$ 0.4 and 0.24 ) showed a weak relationship.

Next, we examined the relationship between each of the above-mentioned variables and $C C$ at the individual sites. This was done to identify any trends in the site-wise relationship between $C C$ and $\rho_{\mathrm{s}} H S, T_{s}$, and $T_{a}$. A decreasing trend in the correlation coefficient $(r)$ with increasing mean tree heights was observed when we examined the snow temperature and the reconstructed cold content for each site $(r=0.75,0.69 .0 .67$ and 0.60 for sites A1, A2, A3, and A4, respectively). Beyond that relationship, 
https://doi.org/10.5194/tc-2021-98

Preprint. Discussion started: 13 April 2021

(c) Author(s) 2021. CC BY 4.0 License.

290 we did not identify any site-wise trends between $C C$ and the other variables, thereby suggesting a weak dependency on forest structure in the relationship between $C C$ and other pertinent variables.
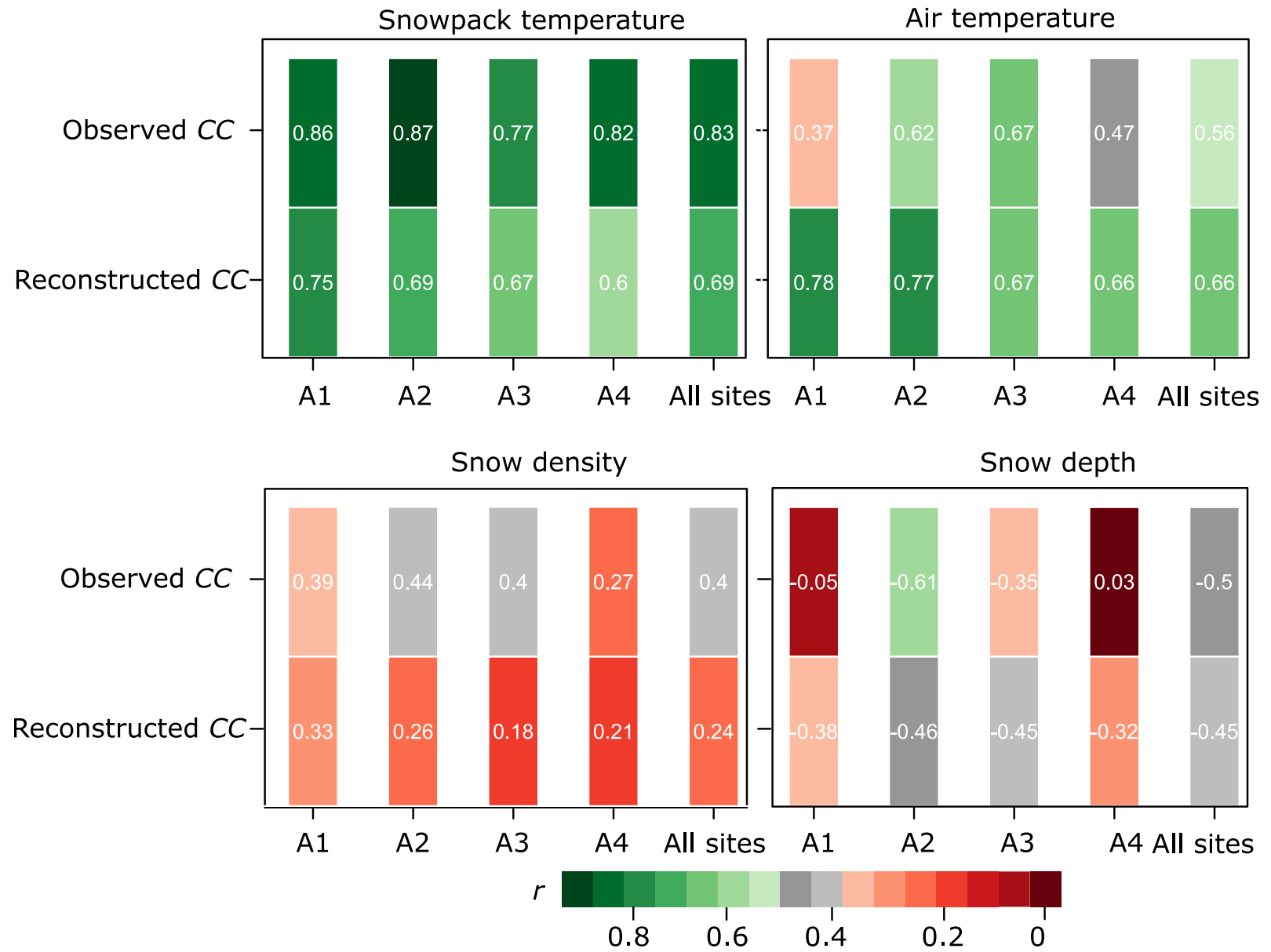

Figure 10. Inter-relationship between $C C$ and snow density, snow depth, snowpack temperature and air temperature. The colour bar represents the absolute value of the Pearson's correlation coefficient $(r)$.

\section{Discussion}

\section{1 $C C$ observations}

As illustrated in Figures 2 and 3, the four experimental sites exhibited unique snow depths, wind speeds, and air temperatures that ultimately resulted in temporal and spatial differences in $C C$. Variability was such that the maximum $C C$ was not always exhibited by the top layer, but also by the middle layer (Fig. 11). For instance, in week 15, the snowpack was denser in the top 
https://doi.org/10.5194/tc-2021-98

Preprint. Discussion started: 13 April 2021

(c) Author(s) 2021. CC BY 4.0 License.

layer than in the middle layer. In week 13, the top layer snowpack was warmer than the layer beneath it. Such patterns in temperature and density are counterexamples of the general patterns depicted in Figure 11.

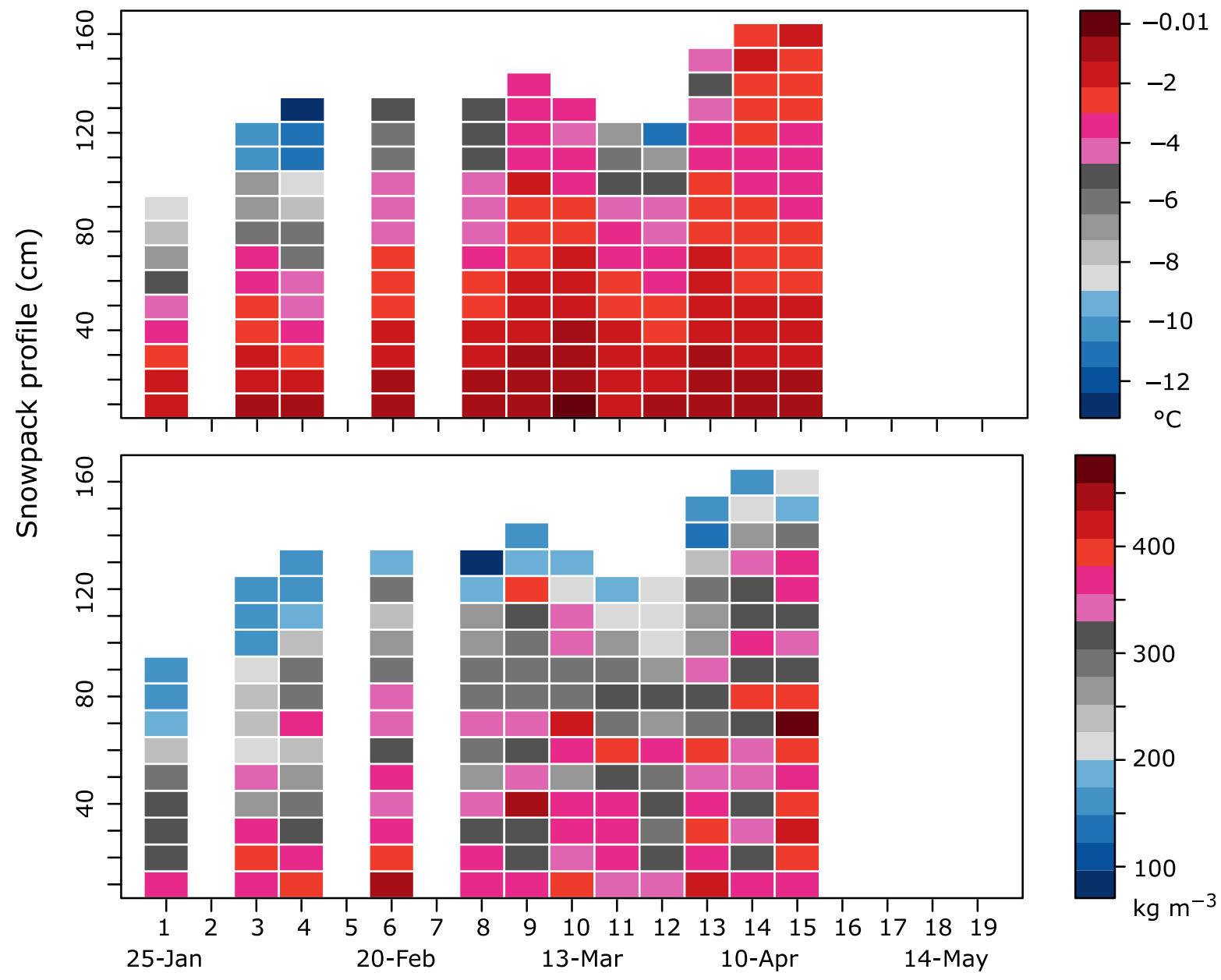

Figure 11. 10-cm snowpack temperature (top) and density (bottom) at site A1. Light blue shading represents spring melt.

Furthermore, the importance of snow mass on $C C$ (total) at the study sites is highlighted in Figure 4. As expected, a deeper

snowpack is typically associated with higher $C C$. For instance, $C C$ peaked at all sites in February, but more $C C$ was observed in the deeper A1 and A2 snowpacks. The same finding holds when $C C$ is averaged over the 15-week period: A2 experienced more snow and higher $C C$, followed by $\mathrm{A} 1$. In both instances (peak and average $C C$ conditions), a deeper snowpack led to larger amplitude of $C C$. In a similar study of alpine and subalpine snowpacks in the Rocky Mountains of Colorado, USA, Jennings et al. (2018) reported peak $C C$ to be 2.6 times greater for the alpine snowpack than for the subalpine location, which they mostly attributed to the higher $S W E$ accumulation at the alpine site.

In early February (during peak $C C$ conditions), the snow depth difference between sites A1 and A2 was very small (Table 3). Nonetheless, A1 exhibited higher $C C$ than A2 (Fig. 4). This is because in addition to snow depth, $C C$ values depend on the density and temperature of the snow (Fig. 11). The higher peak $C C$ found at site A1 can be explained by the higher snow 
https://doi.org/10.5194/tc-2021-98

Preprint. Discussion started: 13 April 2021

(c) Author(s) 2021. CC BY 4.0 License.

(c) (i)

density that is typically associated with higher wind velocities (Vionnet et al., 2012) and wind speed-induced densification.

As illustrated in Figure 2, site A1 was windier than A2. This is expected, as it is well known that wind speed is low within forest canopies (Davis et al., 1997; Harding and Pomeroy, 1996), such as those in site A2.

\subsection{Reconstructed $C C$ time-series}

As mentioned previously, gaps between weekly snowpit surveys failed to capture short-lived events such as warm and cold spells or rain-on-snow events. In an attempt to produce higher frequency $C C$ time series, we used the CLASS land surface model to simulate 30-min bulk snow density and SWE (Fig. 5). Given the limitations of bulk estimations, which are often too broad to properly describe all snowpack processes (Roy et al., 2013), several studies have opted for a multilayer snow model (Brun et al., 1997; Lehning et al., 2002; Vionnet et al., 2012). Our study explored the (simpler) hybrid procedure proposed by Andreadis et al. (2009). Using this method, we generated snow density values which support the derivation of $C C$ time series that are more prone to capturing short-lived events (Fig. 8). As reported in weekly snowpit surveys, the simulated $C C$ time series suggest that the highest peak in $C C$ occurred at site $\mathrm{A} 1$ and the highest peak in mean $C C$ was at site $\mathrm{A} 2$. In both instances (snowpit observations and reconstructed $C C$ ), there was a decrease in peak $C C$ with an increase in tree height (Fig. 8 and Table 3). Parajuli et al. (2020b) explored the spatiotemporal variability of $S W E$ in the same forest and reported reduced snow accumulation beneath canopies composed of taller trees. Initially, site A1, with lower vegetation, experienced more snow than the other sites (Table 3). Favourable conditions (lower temperature and deeper and denser snowpack) supported the occurrence of higher peak $C C$ at this site (Fig. 2, Fig. 11 and Table 3). However, over the entire winter, site A2 experienced more snow and higher amplitude of $C C$ values than the snowpack at site A1 (Fig. 9). In order to understand this variability in $C C$ across all four sites, our analysis revealed that there were $60 \%$ occurrences where amplitude of $C C$ was higher at site A2 than at A1, contributing to the overall $C C$ at site A2.

For site A3, there were $32 \%$ occurrences where amplitude of $C C$ values was higher than at A1, beginning in early February and continuing through the rest of the study period (Fig. 9). Most of the time, the measured snow depth at site A3 was also shallower than at site A1. We hypothesized that cold air pooling might explain this phenomenon. During stable atmospheric boundary layer conditions, with weak synoptic forcing, there is reduced wind flow. This results in thermal decoupling in the valley depression, which favours the formation of a cold air pool (Fujita et al., 2010; Mott et al., 2016). This is substantiated by the rapid cooling of near-surface air within the valley depression, typically at night or early in the morning (Smith et al.,

340 2010). As site A3 is situated in a valley depression (Fig. 1), cold air pooling most likely explains the higher peak $C C$ at this location (Fig. 2).

Based on Figures 2 and 9, snow depth and air temperature appear to influence $C C$ distribution across the study sites. In general, the observed and simulated snowpack $C C$ values at all sites were strongly (positively) correlated with snowpack temperature and air temperature, and weakly correlated with the snow density and snow depth values (Figure 10). It should also be noted 345 that the snowpack $C C$ values at all sites only showed negative correlations with snow depth (Fig. 10). Based on $C C$ observations and the hybrid procedure, we were able to identify a relationship between the mean $C C$ and the tree height (Table 
3 and Fig. 8). However, we were unable to report any trends in the site-wise relationship between $C C$ and the above-mentioned variables (Fig. 10). Conversely, Jennings et al. (2018) attempted to establish a relationship between $C C$ development and the cumulative mean of air temperature across the alpine and sub-alpine sites in the Rocky Mountains in Colorado, USA, but were unsuccessful.

\subsection{Sources of uncertainty}

One of the shortcomings of our multilayer snowpack scheme is the use of empirical fresh snow density estimates. Russell et al. (2020) explored a range of fresh snow density formulations and concluded that a constant value of $100 \mathrm{~kg} \mathrm{~m}^{-3}$ provided a better outcome than most empirical formulations. Nonetheless, they tested some empirical formulations that omitted the influence of wind speed on snow densification, as in the Brun et al. (1989) method. We compare observations to snow density estimates (top $10 \mathrm{~cm}$ ) from three empirical methods: Diamond-Lowry (Russell et al., 2020), Hedstrom-Pomeroy (Hedstrom and Pomeroy, 1998), and Brun (Shrestha et al., 2010; Vionnet et al., 2012) (Fig. 11). These formulations are typically used to determine snowpack density. Examples include a study by Gouttevin et al. (2015) where the Brun method was used, and one by Bartlett et al. (2006) where the Hedstrom-Pomeroy method was implemented.

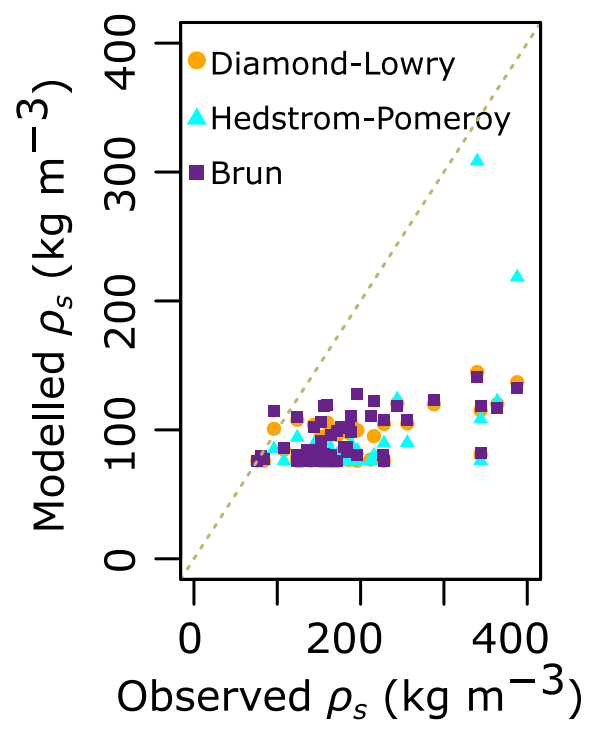

Figure12. Observed versus modelled snow densities (first $10 \mathrm{~cm}$ ) using three different methods.

All three empirical methods performed poorly (Diamond-Lowry [Pbias $=-53.1 \%]$, Hedstrom-Pomeroy [Pbias $=-51.6 \%$, and Brun $[$ Pbias $=-50.2 \%]$ ), greatly underestimating snow density (Fig. 7). Several multilayer snow models use the Brun formula/method to estimate fresh snow density (e.g. Shrestha et al., 2010; Vionnet et al., 2012). When the same (Brun method) empirical snow density model was adopted into our methodology, the snow density estimates (especially the top layer) were disastrous (Figure 7). 
https://doi.org/10.5194/tc-2021-98

Preprint. Discussion started: 13 April 2021

(c) Author(s) 2021. CC BY 4.0 License.

(c) (i)

In a slightly different context, Raleigh and Small (2017) concluded that snow density modelling was a major source of uncertainty when studying catchment $S W E$ derived from satellite data. Additionally, several errors and biases could arise due to poor data quality and modelling deficiencies, thereby affecting the snowmelt models (Parajuli et al., 2020a; Raleigh et al., 2015, 2016; Rutter et al., 2009). For instance, Jennings et al. (2018) applied the SNOWPACK multilayer model and reported an overestimation in fresh-snow temperature. As reported in the present study, $C C$ depends heavily on snowpack temperature. The quality of model inputs also influences model performance. For example, sites A1 and A2 benefitted from local flux tower measurements, but such direct measurements were not available for sites A3 and A4, for which many assumptions were necessary in order to create/complete missing input time series. This problem has also been observed in several other studies(e.g. Pomeroy et al., 2007; Qi et al., 2017). Important snowpack properties beyond just $C C$, such as thermal conductivity (Oldroyd et al., 2013) and snow interception (Hedstrom and Pomeroy, 1998) also need to be further addressed. Therefore, future research that utilizes the physically-based snow model and describes the internal snowpack processes should focus on improving snow density estimations.

\section{Conclusion}

380 The purpose of this study was to document the spatial variability of $C C$ in a humid boreal forest, using detailed measurements supplemented by physically-based and empirical model outputs. The studied boreal forest is characterized by a non-uniform stand structure that led to site-to-site variations in the 10-cm weekly observations of $C C$. Areas with lower vegetation had the highest snow accumulation and thus resulted in the largest peaks in total $C C$, while the juvenile forest experienced the highest amplitude of average $C C$ over the 15 weeks.

385 The Canadian Land Surface Scheme model was then coupled with complementary empirical formulations to construct bulk, followed by 10-cm, 30-min snow density time series. Both CLASS and the empirical formulations supplied reasonable snow density and $C C$ estimates. When the latter $10-\mathrm{cm}$ time series were split into three layers, the bottom and the middle layers also resulted in reasonable simulations. However, modelling of the top layer was not as successful. The constructed time series were used to illustrate the influence of phenomena that are not detectable when only snowpit data are used, such as rain-onsnow episodes or the formation of cold air pools at the bottom of the valley.

We used the Pearson's correlation coefficient ( $r$ ) to identify the role of pertinent variables (snow density, snowpack temperature, snow depth and air temperature) that affect the distribution of $C C$ at our boreal forest sites. Snowpack and air temperature appeared to be highly influential on $C C$ distribution compared to the depth and the density of the snowpack. Our study was supported by 30-min time step time series of 10-cm snow temperature profiles and bias-corrected precipitation inputs. The inclusion of such inputs helped us to reduce errors and biases. This study also highlighted the uncertainty associated with fresh snow density estimates when simulating the physically-based snowmelt models.

Data availability: The data that support the findings in this study will be available in the public repository. 
https://doi.org/10.5194/tc-2021-98

Preprint. Discussion started: 13 April 2021

(c) Author(s) 2021. CC BY 4.0 License.

(c) (i)

Author contributions: AP and DFN (occasionally) extracted the data from the field. AP, DFN and FA designed the study. AP wrote the manuscript and analyzed the data. DFN and FA provided constructive feedback to improve the quality of the manuscript. MA performed CLASS simulations.

Conflicts of interest: Authors declare no conflicts of interest.

405

Acknowledgements: This research is a part of the EVAP project which was funded by Natural Sciences and Engineering Council of Canada (NSERC), Ouranos (Consortium on Regional Climatology and Adaptation to Climate Change), HydroQuébec, Environment and Climate Change Canada, and Ministère de l'Environnement et de la Lutte aux changements climatiques through grant RDCPJ-477125-14. We would like to express our sincere gratitude to Professor Sylvain Jutras for kindly providing the necessary sensors and support for managing the logistics of the field experiment. We conducted two successful winter campaigns, thanks to the generous support from Professor André Desrochers, who provided a snowmobile. The authors would like to thank François Larochelle and Martine Lapointe for providing some of the equipment and helping in the design of the snow profiling stations. Our study would have been incomplete without support from Annie-Claude Parent who participated in the harsh winter field campaign, managed the necessary logistics and helped conduct the field work. We

415 would like to express our deepest gratitude to Benjamin Bouchard and Médéric Girard, who assisted in data collection. The authors are indebted to the Montmorency Forest staff, including Robert Côté and Charles Villeneuve, who provided generous support for managing the logistics throughout the study area. Thanks to group members Bram Hadiwijaya, Pierre-Erik Isabelle, Oliver S. Schilling, Judith Fournier, Alicia Talbot Lanciault, Georg Lackner, Carine Poncelet, Amandine Pierre, Guillaume Hazemann, Marco Alves, Adrien Pierre, Antoine Thiboult, and interns Fabien Gaillard Blancard, Jonas Götte, Kelly Proteau, and PEGEAUX members, who participated in the challenging winter field campaign.

\section{References}

Alves, M., Music, B., Nadeau, D. F. and Anctil, F.: Comparing the performance of the maximum entropy production model with a land surface scheme in simulating surface energy fluxes, J. Geophys. Res. Atmos., 124(6), 3279-3300, doi:10.1029/2018JD029282, 2019.

Alves, M., Nadeau, D. F., Music, B., Anctil, F. and Parajuli, A.: On the performance of the Canadian Land Surface Scheme driven by the ERA5 reanalysis over the Canadian boreal forest, J. Hydrometeorol., 21(6), 1383-1404, doi:10.1175/jhmd-19-0172.1, 2020.

Anderson, E. A.: A point energy and mass balance model of a snow cover, US Department of Commerce, National Oceanic and Atmospheric Administration, National Weather Service, Office of Hydrology, 1976. 
https://doi.org/10.5194/tc-2021-98

Preprint. Discussion started: 13 April 2021

(c) Author(s) 2021. CC BY 4.0 License.

(c) (i)

Andreadis, K. M., Storck, P. and Lettenmaier, D. P.: Modeling snow accumulation and ablation processes in forested environments, Water Resour. Res., 45(5), 1-13, doi:10.1029/2008WR007042, 2009.

Barnett, T. P., Adam, J. C. and Lettenmaier, D. P.: Potential impacts of a warming climate on water availability in snowdominated regions, Nature, 438(7066), 303-309, doi:10.1038/nature04141, 2005.

Bartlett, P. A. and Verseghy, D. L.: Modified treatment of intercepted snow improves the simulated forest albedo in the Canadian Land Surface Scheme, Hydrol. Process., 29(14), 3208-3226, doi:10.1002/hyp.10431, 2015.

Bartlett, P. A., MacKay, M. D. and Verseghy, D. L.: Modified snow algorithms in the Canadian land surface scheme: Model runs and sensitivity analysis at three boreal forest stands, Atmosphere-Ocean, 44(3), 207-222, doi:10.3137/ao.440301, 2006.

Brun, E., Martin, E., Simon, V., Gendre, C. and Coleou, C.: An energy and mass model of snow cover suitable for operational avalanche forecasting, J. Glaciol., 35(121), 333-342, doi:10.1017/S0022143000009254, 1989.

Brun, E., Martin, E. and Spiridonov, V.: Coupling a multi-layered snow model with a GCM, Ann. Glaciol., 25(2), 66-72, doi:10.1017/s0260305500013811, 1997.

Davis, R. E., Hardy, J. P., Ni, W., Woodcock, C., McKenzie, J. C., Jordan, R. and Li, X.: Variation of snow cover ablation in the boreal forest: A sensitivity study on the effects of conifer canopy, J. Geophys. Res. Atmos., 102(D24), 29389-29395, doi:10.1029/97JD01335, 1997.

DeWalle, D. R. and Rango, A.: Principles of snow hydrology, 1st ed., Cambridge University Press, New York., 2008.

Essery, R., Morin, S., Lejeune, Y. and Ménard, C.: A comparison of 1701 snow models using observations from an alpine site, Adv. Water Resour., 55, 131-148, doi:10.1016/j.advwatres.2012.07.013, 2013.

Fujita, K., Hiyama, K., Iida, H. and Ageta, Y.: Self-regulated fluctuations in the ablation of a snow patch over four decades, Water Resour. Res., 46(11), 1-9, doi:10.1029/2009WR008383, 2010.

Gouttevin, I., Lehning, M., Jonas, T., Gustafsson, D. and Mölder, M.: A two-layer canopy model with thermal inertia for an improved snowpack energy balance below needleleaf forest (model SNOWPACK, version 3.2.1, revision 741), Geosci. Model Dev., 8(8), 2379-2398, doi:10.5194/gmd-8-2379-2015, 2015.

Harding, R. J. and Pomeroy, J. W.: The energy balance of the winter boreal landscape, J. Clim., 9(11), 2778-2787, doi:10.1175/1520-0442(1996)009<2778:TEBOTW>2.0.CO;2, 1996.

Hedstrom, N. R. and Pomeroy, J. W.: Measurements and modelling of snow interception in the boreal forest, Hydrol. Process., 12(10-11), 1611-1625, doi:10.1002/(SICI)1099-1085(199808/09)12:10/11<1611::AID-HYP684>3.0.CO;2-4, 1998.

Isabelle, P., Nadeau, D. F., Rousseau, A. N., Anctil, F., Jutras, S. and Music, B.: Impacts of high precipitation on the energy and water budgets of a humid boreal forest, Agric. For. Meteorol., 280, 1-13, doi:10.1016/j.agrformet.2019.107813, 2020.

Isabelle, P. E., Nadeau, D. F., Asselin, M. H., Harvey, R., Musselman, K. N., Rousseau, A. N. and Anctil, F.: Solar radiation transmittance of a boreal balsam fir canopy: Spatiotemporal variability and impacts on growing season hydrology, Agric. For. Meteorol., 263, 1-14, doi:10.1016/j.agrformet.2018.07.022, 2018. 
https://doi.org/10.5194/tc-2021-98

Preprint. Discussion started: 13 April 2021

(c) Author(s) 2021. CC BY 4.0 License.

(c) (i)

Jennings, K. S., Kittel, T. G. F. and Molotch, N. P.: Observations and simulations of the seasonal evolution of snowpack cold content and its relation to snowmelt and the snowpack energy budget, Cryosph., 12(5), 1595-1614, doi:10.5194/tc-121595-2018, 2018.

Jost, G., Moore, R. D., Smith, R. and Gluns, D. R.: Distributed temperature-index snowmelt modelling for forested catchments, J. Hydrol., 420-421, 87-101, doi:10.1016/j.jhydrol.2011.11.045, 2012.

Koivusalo, H., Heikinheimo, M. and Karvonen, T.: Test of a simple two-layer parameterisation to simulate the energy balance and temperature of a snow pack, Theor. Appl. Climatol., 70(1-4), 65-79, doi:10.1007/s007040170006, 2001.

Lehning, M., Bartelt, P., Brown, B. and Fierz, C.: A physical SNOWPACK model for the Swiss avalanche warning Part III: Meteorological forcing, thin layer formation and evaluation, Cold Reg. Sci. Technol., 35(3), 169-184, doi:10.1016/S0165-232X(02)00072-1, 2002.

Leonardini, G., Anctil, F., Abrahamowicz, M., Gaborit, É., Vionnet, V., Nadeau, D. F. and Fortin, V.: Evaluation of the soil, vegetation, and snow (SVS) land surface model for the simulation of surface energy fluxes and soil moisture under snowfree conditions, Atmosphere, 11(3), 278, doi:10.3390/atmos11030278, 2020.

Lundquist, J. D. and Lott, F.: Using inexpensive temperature sensors to monitor the duration and heterogeneity of snowcovered areas, Water Resour. Res., 44(4), 1-6, doi:10.1029/2008WR007035, 2008.

Mahat, V. and Tarboton, D. G.: Canopy radiation transmission for an energy balance snowmelt model, Water Resour. Res., 48(1), 1-16, doi:10.1029/2011WR010438, 2012.

Marks, D. and Winstral, A.: Comparison of snow deposition, the snow cover energy balance, and snowmelt at two sites in a semiarid mountain basin, J. Hydrometeorol., 2(3), 213-227, doi:10.1175/15257541(2001)002<0213:COSDTS>2.0.CO;2, 2001.

Marks, D., Kimball, J., Tingey, D. and Link, T.: The sensitivity of snowmelt processes to climate conditions and forest cover during rain-on-snow: a case study of the 1996 Pacific Northwest flood, Hydrol. Process., 12(10-11), 1569-1587, doi:10.1002/(SICI)1099-1085(199808/09)12:10/11<1569::AID-HYP682>3.0.CO;2-L, 1998.

Molotch, N. P., Brooks, P. D., Burns, S. P., Litvak, M., Monson, R. K., McConnell, J. R. and Musselman, K. N.: Ecohydrological controls on snowmelt partitioning in mixed-conifer sub-alpine forests, Ecohydrology, 2, 129-142, doi:10.1002/eco.48, 2009.

Mosier, T. M., Hill, D. F. and Sharp, K. V.: How much cryosphere model complexity is just right? Exploration using the conceptual cryosphere hydrology framework, Cryosph., 10(5), 2147-2171, doi:10.5194/tc-10-2147-2016, 2016.

Mott, R., Paterna, E., Horender, S., Crivelli, P. and Lehning, M.: Wind tunnel experiments: Cold-air pooling and atmospheric decoupling above a melting snow patch, Cryosph., 10(1), 445-458, doi:10.5194/tc-10-445-2016, 2016.

495 Musselman, K., Molotch, N. and Brooks, P.: Effect of vegetation on snow accumulation and ablation in a mid-latitude subalpine forest, Hydrol. Process., 22(15), 2267-2274, doi:10.1002/hyp.7050, 2008.

Oldroyd, H. J., Higgins, C. W., Huwald, H., Selker, J. S. and Parlange, M. B.: Thermal diffusivity of seasonal snow determined from temperature profiles, Adv. Water Resour., 55, 121-130, doi:10.1016/j.advwatres.2012.06.011, 2013. 
https://doi.org/10.5194/tc-2021-98

Preprint. Discussion started: 13 April 2021

(c) Author(s) 2021. CC BY 4.0 License.

\section{(c) (1)}

Parajuli, A., Nadeau, D. F., Anctil, F., Schilling, O. S. and Jutras, S.: Does data availability constrain temperature-index snow model ? A case study in the humid boreal forest, Water, 12(8), 1-22, doi:10.3390/w12082284, 2020a.

Parajuli, A., Nadeau, D. F., Anctil, F., Parent, A.-C., Bouchard, B., Girard, M. and Jutras, S.: Exploring the spatiotemporal variability of the snow water equivalent in a small boreal forest catchment through observation and modelling, Hydrol. Process., 34(11), 2628-2644, doi:10.1002/hyp.13756, 2020 b.

Pierre, A., Jutras, S., Smith, C., Kochendorfer, J., Fortin, V. and Anctil, F.: Evaluation of catch efficiency transfer functions for unshielded and single-alter-shielded solid precipitation measurements, J. Atmos. Ocean. Technol., 36(5), 865-881, doi:10.1175/JTECH-D-18-0112.1, 2019.

Pomeroy, J. W., Gray, D. M., Brown, T., Hedstrom, N. R., Quinton, W., Granger, R. J. and Carey, S. K.: The cold regions hydrological model: a platform for basing process representation and model structure on physical evidence, Hydrol. Process., 21(19), 2650-2667, doi:10.1002/hyp.6787, 2007.

Qi, J., Li, S., Jamieson, R., Hebb, D., Xing, Z. and Meng, F. R.: Modifying SWAT with an energy balance module to simulate snowmelt for maritime regions, Environ. Model. Softw., 93, 146-160, doi:10.1016/j.envsoft.2017.03.007, 2017.

Raleigh, M. S. and Small, E. E.: Snowpack density modeling is the primary source of uncertainty when mapping basin-wide SWE with lidar, Geophys. Res. Lett., 44(8), 3700-3709, doi:10.1002/2016GL071999, 2017.

Raleigh, M. S., Lundquist, J. D. and Clark, M. P.: Exploring the impact of forcing error characteristics on physically based snow simulations within a global sensitivity analysis framework, Hydrol. Earth Syst. Sci., 19(7), 3153-3179, doi:10.5194/hess-19-3153-2015, 2015.

Raleigh, M. S., Livneh, B., Lapo, K. and Lundquist, J. D.: How does availability of meteorological forcing data impact physically based snowpack simulations?, J. Hydrometeorol., 17(1), 99-120, doi:10.1175/JHM-D-14-0235.1, 2016.

Roy, A., Royer, A., Montpetit, B., Bartlett, P. A. and Langlois, A.: Snow specific surface area simulation using the one-layer snow model in the Canadian LAnd Surface Scheme (CLASS), Cryosph., 7(3), 961-975, doi:10.5194/tc-7-961-2013, 2013.

Russell, M., Eitel, J. U. H., Maguire, A. J. and Link, T. E.: Toward a novel laser-based approach for estimating snow interception, Remote Sens., 12(7), 1-11, doi:10.3390/rs12071146, 2020.

Rutter, N., Essery, R., Pomeroy, J., Altimir, N., Andreadis, K., Baker, I., Barr, A., Bartlett, P., Boone, A., Deng, H., Douville, H., Dutra, E., Elder, K., Ellis, C., Feng, X., Gelfan, A., Goodbody, A., Gusev, Y., Gustafsson, D., Hellström, R., Hirabayashi, Y., Hirota, T., Jonas, T., Koren, V., Kuragina, A., Lettenmaier, D., Li, W. P., Luce, C., Martin, E., Nasonova, O., Pumpanen, J., Pyles, R. D., Samuelsson, P., Sandells, M., Schädler, G., Shmakin, A., Smirnova, T. G., Stähli, M., Stöckli, R., Strasser, U., Su, H., Suzuki, K., Takata, K., Tanaka, K., Thompson, E., Vesala, T., Viterbo, P., Wiltshire, A., Xia, K., Xue, Y. and Yamazaki, T.: Evaluation of forest snow processes models (SnowMIP2), J. Geophys. Res. Atmos., 114(D6), 1-18, doi:10.1029/2008JD011063, 2009. 
https://doi.org/10.5194/tc-2021-98

Preprint. Discussion started: 13 April 2021

(c) Author(s) 2021. CC BY 4.0 License.

(c) (i)

Schaefli, B., Hingray, B. and Musy, A.: Climate change and hydropower production in the Swiss Alps: Quantification of potential impacts and related modelling uncertainties, Hydrol. Earth Syst. Sci., 11(3), 1191-1205, doi:10.5194/hess-111191-2007, 2007.

Schilling, O. S., Parajuli, A., Tremblay Otis, C., Müller, T. U., Antolinez Quijano, W., Tremblay, Y., Brennwald, M. S., Nadeau, D. F., Jutras, S., Kipfer, R. and Therrien, R.: Quantifying groundwater recharge dynamics and unsaturated zone processes in snow-dominated catchments via on-site dissolved gas analysis, Water Resour. Res., 57(2), 1-24, doi:10.1029/2020wr028479, 2021.

540 Seligman, Z. M., Harper, J. T. and Maneta, M. P.: Changes to snowpack energy state from spring storm events, Columbia River headwaters, Montana, J. Hydrometeorol., 15(1), 159-170, doi:10.1175/JHM-D-12-078.1, 2014.

Shrestha, M., Wang, L., Koike, T., Xue, Y. and Hirabayashi, Y.: Improving the snow physics of WEB-DHM and its point evaluation at the SnowMIP sites, Hydrol. Earth Syst. Sci., 14(12), 2577-2594, doi:10.5194/hess-14-2577-2010, 2010.

Smith, S. A., Brown, A. R., Vosper, S. B., Murkin, P. A. and Veal, A. T.: Observations and simulations of cold air pooling in valleys, Boundary-Layer Meteorol., 134(1), 85-108, doi:10.1007/s10546-009-9436-9, 2010.

Tarboton, D. G., Chowdhury, T. G. and Jackson, T. H.: A spatially distributed energy balance snowmelt model, Proceedings of Symposium on Biogeochemistry of Seasonally Snow, 1994.

U.S. Army Corps of Engineers.: Snow hydrology: Summary report of the snow investigations, North Pacific Division, Portland District, USA., 1956.

550 Valéry, A., Andréassian, V. and Perrin, C.: 'As simple as possible but not simpler': What is useful in a temperature-based snow-accounting routine? Part 2 - Sensitivity analysis of the Cemaneige snow accounting routine on 380 catchments, J. Hydrol., 517, 1176-1187, doi:10.1016/j.jhydrol.2014.04.058, 2014.

Verseghy, D., Brown, R. and Wang, L.: Evaluation of CLASS snow simulation over Eastern Canada, J. Hydrometeorol., 18(5), 1205-1225, doi:10.1175/JHM-D-16-0153.1, 2017.

555 Verseghy, D. L.: CLASS-A Canadian land surface scheme for GCMS. I. soil model, Int. J. Climatol., 11(2), 111-133, doi:10.1002/joc.3370110202, 1991.

Vionnet, V., Brun, E., Morin, S., Boone, A., Faroux, S., Le Moigne, P., Martin, E. and Willemet, J. M.: The detailed snowpack scheme Crocus and its implementation in SURFEX v7.2, Geosci. Model Dev., 5(3), 773-791, doi:10.5194/gmd-5-7732012, 2012.

Wigmosta, M., Nijssen, B. and Storck, P.: The distributed hydrology soil vegetation model., Math. Model. Small Watershed Hydrol. Appl., 7-42 [online] Available from: http://www.cabdirect.org/abstracts/20033121322.html, 2002.

Wigmosta, M. S., Vail, L. W. and Lettenmaier, D. P.: A distributed hydrology-vegetation model for complex terrain, Water Resour. Res., 30(6), 1665-1679, doi:10.1029/94WR00436, 1994. 